\title{
Corneal Re-epithelialization Stimulated by Diadenosine Polyphosphates Recruits RhoA/ROCK and ERK1/2 Pathways
}

\author{
Aránzazu Mediero, ${ }^{1}$ Ana Guzmán-Aranguez, ${ }^{1}$ Almudena Crooke, ${ }^{1}$ Assumpta Peral, ${ }^{2}$ and \\ Jesús Pintor ${ }^{1}$
}

Purpose. To investigate the role of ERK1/2 and RhoA/ROCK intracellular pathways in the modification of corneal re-epithelialization when stimulated by the diadenosine polyphosphates $\mathrm{Ap}_{4} \mathrm{~A}$ and $\mathrm{Ap}_{3} \mathrm{~A}$.

MeTHODS. In wounded confluent SIRC (Statens Seruminstitut rabbit cornea) cell monolayers and in the presence or absence of $\mathrm{Ap}_{4} \mathrm{~A}$ or $\mathrm{Ap}_{3} \mathrm{~A} 100 \mu \mathrm{M}$, a battery of $\mathrm{P} 2$ receptor antagonists and inhibitors of tyrosin kinases, MAPK, and cytoskeleton pathways (AG1478 $100 \mu \mathrm{M}$, U0126 $100 \mu \mathrm{M}$, Y27632 $100 \mathrm{nM}$, and (-)-blebbistatin $10 \mu \mathrm{M} ; n=8$ each) were assayed. Also, the activation of ERK1/2 and ROCK-I was examined by Western blot assay after treatment with $\mathrm{Ap}_{4} \mathrm{~A}$ and $\mathrm{Ap}_{3} \mathrm{~A}(100 \mu \mathrm{M})$, with or without suramin, RB-2, U0126, and Y27632. The intracellular distribution of pERK and ROCK-I was examined in the presence of $\mathrm{Ap}_{4} \mathrm{~A}$ or $\mathrm{Ap}_{3} \mathrm{~A}(100 \mu \mathrm{M})$ with U0126 and Y27632 (100 nM).

Results. In the presence of $\mathrm{Ap}_{4} \mathrm{~A}, \mathrm{U} 0126, \mathrm{Y} 27632$, AG1478, and $(-)$-blebbistatin, reduced the migration rate compared to the effect of $\mathrm{Ap}_{4} \mathrm{~A}$ alone $(P<0.0001, P<0.001, P<0.01$, and $P<0.1$ versus $A p_{4} A$, respectively). In the presence of $A p_{3} A$ $100 \mu \mathrm{M}, \mathrm{U} 0126$ and Y27632 accelerated the migration rate when compared with the effect of $\mathrm{Ap}_{3} \mathrm{~A}$ alone, whereas AG1478 and $(-)$-blebbistatin $\left(P<0.0001\right.$ versus $\left.A_{3} A\right)$ slowed the migration rate. Western blot assays demonstrated that both dinucleotides activated the ERK1/2 pathway but only $\mathrm{Ap}_{4} \mathrm{~A}$ activated the ROCK-I pathway. The intracellular distribution of pERK1/2 and ROCK-I reflected cross-talk between these two pathways.

Conclusions. The activation of the $\mathrm{Ap}_{4} \mathrm{~A} / \mathrm{P}_{2} \mathrm{Y}_{2}$ receptor, accelerates corneal epithelial cell migration during wound healing with the activation of MAPK and cytoskeleton pathways, whereas activation of the $A p_{3} \mathrm{~A} / \mathrm{P} 2 \mathrm{Y}_{6}$ receptor signals only the MAPK pathway. (Invest Ophthalmol Vis Sci. 2008;49: 4982-4992) DOI:10.1167/iovs.07-1583

$\mathrm{D}$ inucleoside polyphosphates $\left(\mathrm{Np}_{n} \mathrm{~N}^{\prime}\right)$ are compounds that have interesting physiological properties in various tissues similar to those of mononucleotides. ${ }^{1-3}$ The most commonly

From Departamentos de ${ }^{1}$ Bioquímica y Biología Molecular IV y de ${ }^{2}$ Óptica II, E.U. Óptica, Universidad Complutense de Madrid, Madrid, Spain.

Supported by Grants NEUROTRANS-CM Ref. 0253-2006 and PR1/07 to 14890 from Universidad Complutense de Madrid. AM is a fellowship holder from the Universidad Complutense de Madrid.

Submitted for publication December 11, 2007; revised June 9, 2008; accepted September 17, 2008.

Disclosure: A. Mediero, None; A. Guzmán-Aranguez, None; A. Crooke, None; A. Peral, None; J. Pintor, None

The publication costs of this article were defrayed in part by page charge payment. This article must therefore be marked "advertisement" in accordance with 18 U.S.C. $\$ 1734$ solely to indicate this fact.

Corresponding author: Jesús Pintor, Departamento Bioquímica y Biología Molecular IV, Escuela Universitaria de Óptica, Universidad Complutense de Madrid, c/Arcos de Jalón s/n, 28037 Madrid, Spain; jpintor@vet.ucm.es. studied dinucleotides are diadenosine polyphosphates $\left(\mathrm{Ap}_{n} \mathrm{~A}\right.$, where $n=3$ to 7). These compounds mediate a variety of functions, such as inhibition of adenosine kinase and adenylate kinase, ${ }^{4}$ stimulation of nitric oxide release from endothelial cells, ${ }^{5}$ inhibition of platelet aggregation, ${ }^{6}$ and facilitation of neurotransmitter release from synaptic terminals in the central nervous system. ${ }^{7}$

As happens with nucleotides, these compounds exert their functions by binding to membrane receptors termed P2 purinoceptors, ${ }^{8}$ as well as to their own dinucleotide receptors. ${ }^{7}$ P2 receptors are organized into two families: ionotropic $\mathrm{P} 2 \mathrm{X}$ receptors and metabotropic $\mathrm{P} 2 \mathrm{Y}$ receptors. $\mathrm{P} 2 \mathrm{X}$ receptors are formed by two or three subunits that construct an active receptor, ${ }^{9}$ which forms an ATP-gated ion channel that mediates rapid and selective permeability to cations. ${ }^{10}$ Seven P2X receptor subunits $\left(\mathrm{P} 2 \mathrm{X}_{1}\right.$ to $\left.\mathrm{P} 2 \mathrm{X}_{7}\right)$ have been cloned so far. ${ }^{9,11}$ This subtype of $\mathrm{P} 2$ receptors is involved in processes in which the cell is excited by nucleotides, similar to the excitation in neurons. $^{12}$

$\mathrm{P} 2 \mathrm{Y}$ receptors are seven-transmembrane-domain proteins coupled to $G$ proteins that trigger different signal transduction pathways: phospholipase C, adenylate cyclase, or MAPK. ${ }^{13-15}$ Eight different $\mathrm{P} 2 \mathrm{Y}$ receptors have been cloned: $\mathrm{P} 2 \mathrm{Y}_{1}, \mathrm{P}_{2} \mathrm{Y}_{2}$, $\mathrm{P}^{2} \mathrm{Y}_{4}, \mathrm{P}_{2} \mathrm{Y}_{6}, \mathrm{P}_{2} \mathrm{Y}_{11}, \mathrm{P}_{2} \mathrm{Y}_{12}, \mathrm{P} \mathrm{Y}_{13}$, and $\mathrm{P} 2 \mathrm{Y}_{14}{ }^{16}$ Although in general all the receptors are widely distributed, the last four are particularly important in processes such as the maintenance of the vascular tone and platelet aggregation. ${ }^{17,18}$

The presence of diadenosine polyphosphates in ocular fluids and their effect in ocular tissues has already been demonstrated. For instance, diadenosine polyphosphates have been identified in tear and aqueous humor, together with other nucleotides. ${ }^{19}$ They also exert several actions in the eye by stimulating $\mathrm{P} 2$ receptors. These actions include the reduction of intraocular pressure (IOP) and modification of the activity of both neuronal and glial retinal cells. ${ }^{19}$

On the ocular surface, the presence of diadenosine triphosphate $\left(\mathrm{Ap}_{3} \mathrm{~A}\right)$, diadenosine tetraphosphate $\left(\mathrm{Ap}_{4} \mathrm{~A}\right)$, and diadenosine pentaphosphate $\left(A_{5} A\right)$ have been described. ${ }^{20,21}$ They have been found to be involved in modifying the rate of corneal re-epithelialization in New Zealand White rabbits, both in vivo $^{22}$ and in vitro. ${ }^{23}$ We have demonstrated that $\mathrm{Ap}_{4} \mathrm{~A}$ produces acceleration in the rate of corneal re-epithelialization by stimulating $\mathrm{P} 2 \mathrm{Y}_{2}$ receptors, and $\mathrm{Ap}_{3} \mathrm{~A}$ and $A \mathrm{p}_{5} \mathrm{~A}$ exert the opposite effect, delaying corneal re-epithelialization by binding to the $\mathrm{P}^{2} \mathrm{Y}_{6}$ receptor. $^{23}$

Several groups ${ }^{24-26}$ have linked corneal wound healing with the members of the mitogen-activated protein kinase (MAPK) and the RhoA/ROCK family. The MAPK cascade is one of the most ubiquitous signal transduction systems and is activated in response to many extracellular stimuli, such as cellular stress, cell death, and injury. ${ }^{27}$ The Rho family of small GTPases has been implicated in the formation of actin stress fibers and focal adhesions. ${ }^{28,29}$ The effects of Rho appear to be regulated by the activation of Rho-associated kinases (ROCK). ${ }^{30}$ Two isoforms of ROCK (ROCKI/ROK $\beta$ and 
ROCKII/ROK $\alpha$ ) have been identified. ${ }^{31}$ In addition, there is evidence that $\mathrm{P} 2 \mathrm{Y}$ receptors may play a role in signal transduction with the activation of both the MAPK ${ }^{32-34}$ and RhoA/ ROCK cascades. ${ }^{35}$

In the present work, we studied the role of ERK1/2 and RhoA/ROCK pathways in the modification of the re-epithelialization rate triggered by the diadenosine polyphosphates $\mathrm{Ap}_{4} \mathrm{~A}$ and $A_{p_{3}} A$ in an established corneal epithelial cell line: SIRC (Statens Seruminstitut rabbit cornea).

\section{Methods}

\section{Reagents}

The dinucleotides $\mathrm{Ap}_{4} \mathrm{~A}$ and $\mathrm{Ap}_{3} \mathrm{~A}$ were purchased from Sigma-Aldrich (St. Louis, MO). Suramin was from Tocris (Bristol, UK). Several antagonists and inhibitors (reactive blue 2 [RB-2]), U0126, Y27632, and (-)-blebbistatin) were from Sigma-Aldrich, and AG1478 was from Calbiochem (San Diego, CA). Minimum essential medium (MEM) with Earle's salts, L-glutamine, and nonessential amino acids and fetal bovine serum were from Invitrogen (Paisley, UK). Primary antibodies against pERK1/2, ERK-2, ROCK-I, MLC2, goat anti-mouse IgG-HRP secondary antibody, and goat anti-mouse IgG-TRICT secondary antibody were obtained from Santa Cruz Biotechnology (Santa Cruz, CA). Primary antibody against pMLC2 was purchased from Cell Signaling (Izasa S.A., Barcelona, Spain). Bradford reagent and acrylamide-bisacrylamide were from Bio-Rad (Hercules CA; Alcobendas, Madrid, Spain). Nitrocellulose membrane and a chemiluminescence detection system (Hyperfilm ECL) were from GE Healthcare (Barcelona, Spain). Phenylmethylsulfonyl fluoride (PMSF), sodium fluoride (NaF), sodium orthovanadate $\left(\mathrm{Na}_{3} \mathrm{VO}_{4}\right)$, pepstatin A, leupeptin, aprotinin, and NP-40 were from Sigma-Aldrich. The SIRC cells were obtained from American Type Culture Collection (ATCC; LGC Promochem SL, Barcelona, Spain).

\section{Cell Culture}

All animals were treated in accordance with the ARVO Statement for the Use of Animals in Ophthalmic and Vision Research and in accordance with the European Communities Council Directive (89/609/ EEC). Primary corneal epithelial cells were obtained from healthy eyes of adult New Zealand White rabbits euthanized with pentothal sodium. Cell culture was performed according to the protocol previously described. ${ }^{17,23}$ Briefly, the eyes were enucleated, and the globes were placed in Hanks' balanced salt solution (HBSS) while corneal dissection was performed under a dissecting microscope. The cornea was removed along the limbus and cut into pieces. Incubation of the corneas in 1.0 U Dispase II (Roche Molecular Biochemicals, Indianapolis, IN) was performed for 1 hour at $37^{\circ} \mathrm{C}$ in $5 \% \mathrm{CO}_{2}$ and $95 \%$ humidity. The epithelium was peeled from the stroma and placed in $0.05 \%$ trypsin 0.5 M EDTA for 20 minutes at $37^{\circ} \mathrm{C}$. The specimen was collected in a tube containing $10 \mathrm{~mL}$ Dulbecco's modified Eagle's medium (DMEM; Invitrogen) supplemented with $10 \%$ FBS and $1 \%$ penicillin-streptomycin (both from Invitrogen) and centrifuged twice at $1100 \mathrm{rpm}$ for 6 minutes at $4^{\circ} \mathrm{C}$. Finally, the cells were resuspended in DMEM supplemented with $10 \%$ FBS and $1 \%$ penicillin-streptomycin and cultured in six multiwell plates until confluence. They were kept in a $\mathrm{CO}_{2}$ incubator at $37^{\circ} \mathrm{C} 5 \% \mathrm{CO}_{2}$ and $95 \%$ humidity until confluence.

Cells from an established rabbit corneal epithelial cell line (SIRC) were maintained in minimum essential medium (MEM) with Earle's salts, L-glutamine, and nonessential amino acids supplemented with $10 \%$ activated $\mathrm{FBS}$ and incubated at $37^{\circ} \mathrm{C}$ in $5 \% \mathrm{CO}_{2}$ and $95 \%$ humidity until confluence.

\section{Migration Assays}

To determine the correlation between primary corneal epithelial cells and the SIRC cell line, we performed a migration assay on SIRC cells. $\mathrm{Ap}_{4} \mathrm{~A}$ or $\mathrm{Ap}_{3} \mathrm{~A}(100 \mu \mathrm{M})$ was added to wounded monolayers according to a protocol described for primary cultures. ${ }^{23}$ Briefly, SIRC confluent monolayers were wounded by scraping the cell monolayer with a pipette tip. ${ }^{23}$ The initial wound size and shape were intended $(60,000-$ $80,000 \mu \mathrm{m}^{2}$ ) to take into account the variations in wound closure due to size, so that healing shared the same mechanistic features as previously indicated in other investigations. ${ }^{36}$ Wound area measurements (for each treatment) were collected from eight different wells and averaged (mean \pm SEM). These eight experiments were performed in four independent cell cultures. The cells were challenged with the dinucleotide dose for 2 minutes in Locke medium, to avoid interference by components of media such as DMEM. ${ }^{37}$ After incubation, the cells were washed and fresh MEM was added. A control experiment was performed by challenging the wounded monolayers with Locke medium along $(n=8)$. The dinucleotide dose was added to the wound at time 0 and 6 hours, as previously described for rabbits. ${ }^{22}$ Images were captured every 2 hours during the first 10 hours and at 24 hours after the beginning of the experiment. Wounds were measured with microscope software (LSM 5 Pascal software and Axiovert 200M microscope; Carl Zeiss Meditec, Oberkochen, Germany).

To study the effect that several antagonists against the MAPK and RhoA/ROCK pathways have on the corneal epithelial migration rate in the presence or absence of $\mathrm{Ap}_{4} \mathrm{~A}$ or $\mathrm{Ap}_{3} \mathrm{~A}(100 \mu \mathrm{M})$, we placed U0126 $100 \mu \mathrm{M}$, or AG1478 $(100 \mu \mathrm{M})$, or inhibitors of the actin cytoskeleton pathway (Y27632, $100 \mathrm{nM}$ and (-)-blebbistatin, $10 \mu \mathrm{M}$ ) for 30 minutes (after medium removal) in Locke medium. In the presence of the inhibitors, $\mathrm{Ap}_{4} \mathrm{~A}$ or $\mathrm{Ap}_{3} \mathrm{~A}(100 \mu \mathrm{M})$ was added to the culture, and the cells were exposed for 2 minutes. After this incubation, the cells were washed, and fresh MEM was added. The dinucleotide/antagonist dose was added to the wound at time 0 and 6 hours, as previously described. Images were captured every 2 hours during the first 10 hours and at 24 hours after the beginning of the experiment.

Between different images, the cells were kept in a $\mathrm{CO}_{2}$ incubator at $37^{\circ} \mathrm{C}$ in $5 \% \mathrm{CO}_{2}$ and $95 \%$ humidity.

\section{Western Blot Analysis}

For Western blot analysis of the activation of ERK1/2 and RhoA/ROCK pathways, SIRC confluent monolayers were wounded as described earlier. In the presence or absence of $\mathrm{Ap}_{4} \mathrm{~A}$ or $\mathrm{Ap}_{3} \mathrm{~A} 100 \mu \mathrm{M}$, the antagonists suramin (for $\mathrm{Ap}_{4} \mathrm{~A}$ ) and RB-2 (for $\mathrm{Ap}_{3} \mathrm{~A}$ ) and the inhibitors U0126 and Y27632 were assayed at $100 \mu \mathrm{M}$ and $100 \mathrm{nM}$, respectively, by using the same protocol as previously described for the migration assays.

After collection, the cells were lysed in $20 \mathrm{mM}$ Tris (pH 7.5), 150 $\mathrm{mM} \mathrm{NaCl}$, Triton X-100 (containing $1 \mathrm{mM}$ PMSF, $1 \mathrm{mM} \mathrm{NaF}, 1 \mathrm{mM}$ $\mathrm{Na}_{3} \mathrm{VO}_{4}, 1 \mu \mathrm{g} / \mu \mathrm{L}$ pepstatin $\mathrm{A}, 2 \mu \mathrm{g} / \mu \mathrm{L}$ leupeptin, and $1 \mu \mathrm{g} / \mu \mathrm{L}$ aprotinin). After centrifugation at $15,000 \mathrm{rpm} 20$ minutes $4^{\circ} \mathrm{C}$ to remove debris, the supernatants were collected. To separate cytoplasm from the nuclear fraction, we suspended the cells in two volumes of buffer A $\left(\mathrm{MgCl}_{2} 1.5 \mathrm{mM}, \mathrm{KCl} 10 \mathrm{mM}\right.$, and Tris [pH 7.9] $\left.10 \mathrm{mM}\right)$ containing 1 mM PMSF, $1 \mathrm{mM} \mathrm{NaF}, 1 \mathrm{mM} \mathrm{Na} \mathrm{VO}_{4}, 1 \mu \mathrm{g} / \mu \mathrm{L}$ pepstatin $\mathrm{A}, 2 \mu \mathrm{g} / \mu \mathrm{L}$ leupeptin, $1 \mu \mathrm{g} / \mu \mathrm{L}$ aprotinin, and $0.05 \% \mathrm{NP}-40$. After the mixture was centrifuged at $2,500 \mathrm{~g}$, the supernatants containing the cytosolic soluble fraction were collected. The pellet was resuspended in 1 volume of buffer B (glycerol 20\%, $\mathrm{MgCl}_{2} 1.5 \mathrm{mM}, \mathrm{KCl} 10 \mathrm{mM}$, and Tris [pH 7.9] $20 \mathrm{mM}$ ) and 2:3 volume of buffer C (glycerol $20 \%, \mathrm{MgCl}_{2} 1.5 \mathrm{mM}, \mathrm{KCl}$ $1.2 \mathrm{M}$, and Tris [pH 7.9] $20 \mathrm{mM}$ ) containing $1 \mathrm{mM}$ PMSF, $1 \mathrm{mM} \mathrm{NaF}, 1$ $\mathrm{mM} \mathrm{Na} \mathrm{VO}_{4}, 1 \mu \mathrm{g} / \mu \mathrm{L}$ pepstatin $\mathrm{A}, 2 \mu \mathrm{g} / \mu \mathrm{L}$ leupeptin, and $1 \mu \mathrm{g} / \mu \mathrm{L}$ aprotinin. After 45 minutes' incubation on ice, the pellet was centrifuged at $20,000 \mathrm{~g}$, and the supernatants were collected. Protein concentration was determined by Bradford protein assay. Protein $(45 \mu \mathrm{g})$ was subjected to SDS-PAGE (10\% for ERK1/2, 7\% for ROCK-I, and $12 \%$ for pMLC2) and transferred to a nitrocellulose membrane. To block nonspecific binding, we treated the membranes with PBS with 5\% skimmed milk and then incubated them overnight with primary antibodies against pERK1/2, ROCK-I, and pMLC2 diluted 1:1000 in PBS/ Tween-20 $0.05 \%$ containing $2 \%$ skimmed milk. The membranes were then washed three times (10 minutes per wash) with PBS/Tween-20 $0.05 \%$, and further incubated with the goat anti-mouse IgG-HRP sec- 
ondary antibody diluted 1:2000. Proteins were visualized by enhanced chemiluminescence detection according to the manufacturer's protocol (GE Healthcare).

Blots were stripped (1 M Tris [pH 6.8], SDS 10\%, and $\beta$-mercaptoethanol), blocked and reprobed with ERK2 or MLC2 antibody diluted $1: 1000$, to check that all lanes were loaded with the same amount of protein.

Intensities of the respective band were examined by densitometric analysis (Kodak Gel Logic 2000 and Molecular Imaging Software; Eastman Kodak, Grupo Taper, Alcobendas, Madrid, Spain).

\section{Immunocytochemistry for PERK and ROCK-I}

In the presence of $\mathrm{Ap}_{4} \mathrm{~A}$ or $\mathrm{Ap}_{3} \mathrm{~A} 100 \mu \mathrm{M}$ with $\mathrm{U} 0126$ and $\mathrm{Y} 27632$ (100 $\mu \mathrm{M}$ and $100 \mathrm{nM}$, respectively), we tested the intracellular distribution of pERK and ROCK-I, to correlate results from Western Blot assays and to look for a relationship between ERK1/2 and RhoA/ROCK pathways. To localize the nucleus, we used the nucleic acid stain (PicoGreen; Quant-it dsDNA BR Reagent, Quant-iT dsDNA Brand Range Assay Kit; Invitrogen) ${ }^{38}$ because the PicoGreen dsDNA reagent is an ultrasensitive fluorescent nucleic acid stain and can be used for immunostaining with visible fluorescence in green.

SIRC cells were grown to $80 \%$ confluence on coverslips, and the monolayers were wounded as previously described. These monolayers were challenged for 30 minutes with U0126 $(100 \mu \mathrm{M})$ or Y27632 (100 $\mathrm{nM}$ ), and in the presence of the inhibitor, the cells were incubated for 2 minutes with $\mathrm{Ap}_{4} \mathrm{~A}$ or $\mathrm{Ap}_{3} \mathrm{~A} 100 \mu \mathrm{M}$. After this incubation, fresh MEM was added, and the cells were incubated for 1 hour or 15 minutes to obtain the maximum activation for PERK and ROCK-I, respectively. After incubation, three washes in $10 \times$ PBS were performed, and the cells were fixed for 15 minutes at room temperature with $4 \%$ paraformaldehyde in $0.15 \mathrm{M}$ PBS. The cells were washed again with $10 \times \mathrm{PBS}$, and were permeabilized with blocking solution $(1 \times$ PBS, BSA $3 \%$, Triton X-100, and FBS 5\%) for 1 hour at $37^{\circ} \mathrm{C}$, to block nonspecific binding. The cells were then washed with $1 \times$ PBS/BSA 3\% and incubated with primary mouse monoclonal anti-pERK or anti-ROCK-I (both $1: 100$ ) or $1 \times$ PBS/BSA $3 \%$ for negative controls at room temperature for 1 hour. The cells were washed twice in $1 \times$ PBS/BSA $3 \%$ and incubated with the secondary antibody goat anti-mouse IgG-TRICT (1:200) for 1 hour at room temperature. At this time, the costaining with 1:200 green nuclear stain was performed by adding the stain to the secondary antibody solution. Finally, three washes in $1 \times$ PBS were performed, and coverslips were applied to the slides with mounting medium (Invitrogen). The cells were observed by confocal microscope (Axiovert 200M; Carl Zeiss Meditec), equipped with a Pascal confocal module (LSM 5; Carl Zeiss Meditec). All images were managed with the accompanying Pascal software.

\section{Analysis of Data}

To model the nonlinear decrease in wound area during epithelial healing, we used a modified version of a previously described constantvelocity method. ${ }^{36}$ Briefly, migration rates were determined by linear regression of the decrease in wound area during 10 hours of measurements and were obtained by the slope of the regression line expressed as the percentage of decrease in area per hour. The total time of wound closure was calculated by extrapolation of the best fit of the regression line during the healing phase to $100 \%$ closure of each wound tested.

Migration rates, expressed as the estimated migration rate (EMR) and the estimated time for wound closure, presented as estimated healing time (EHT) in treated and control wounds, were compared by ANOVA test. Average values were expressed as the mean \pm SEM. The levels of significance for the differences are indicated in each case in the figure legends.

When we represent linear regression of the decrease in wound area, data are expressed as a percentage of the initial wound width, to normalize variability in wounding from well to well and experiment to experiment according to the same strategy as described in other studies. ${ }^{39,40}$ EMR variations are expressed as the percentage area de- crease in area $\cdot$ hours $^{-1}$, and all data are related to the control (time 0 hours), to minimize the intrinsic values of the medium.

To quantify Western blot analysis of pERK, ROCK-I, and pMLC2, we performed densitometry, and band intensities were relativized to ERK2 or MLC2. Variations in intensity were expressed as a percentage of the control and expressed as the mean \pm SEM, because all data are related to a control, to minimize the intrinsic levels that occur with the wound closure.

Intracellular distribution of pERK1/2 and ROCK-I was determined by densitometric quantification of pERK1/2 and ROCK-I signal intensity in the nucleus and in the cytoplasm of several images $(n=4)$. In each case, the results were expressed as mean \pm SEM and represented in arbitrary units.

\section{Results}

\section{Migration Assays}

To correlate our wound healing results from primary corneal epithelial $^{23}$ cells with the establish cell line SIRC, we performed a migration assay with $\mathrm{Ap}_{4} \mathrm{~A}$ and $\mathrm{Ap}_{3} \mathrm{~A}(100 \mu \mathrm{M})$ in SIRC monolayers. A comparison between the behavior of SIRC cells and primary cultured corneal epithelial cells in migration studies can be performed by comparing Tables 1 and 2 . Values in both systems are almost identical for the effects of $\mathrm{Ap}_{4} \mathrm{~A}$ and $\mathrm{Ap}_{3} \mathrm{~A}$. Therefore, all the experiments regarding the secondmessenger cascades were performed in the SIRC cell line.

Figure 1A, shows the effects of $\mathrm{Ap}_{4} \mathrm{~A}$ and $\mathrm{Ap}_{3} \mathrm{~A}$ on wound healing. As can be seen, $\mathrm{Ap}_{4} \mathrm{~A}$ significantly increased the EMR $(4.35 \% \pm 0.11 \%)$ when compared with the control $(3.28 \% \pm$ $0.27 \%$ ). This change represents a concomitant decrease in EHT, with closure of the wound occurring 8 hours earlier than in the absence of any added substance. On the other hand, $\mathrm{Ap}_{3} \mathrm{~A}$ slowed the migration rate $(2.98 \% \pm 0.17 \%)$ when compared with the control and increased EHT by 3 hours. In Figure $1 \mathrm{~B}$, a series of micrographs in which we can compare the effects of $\mathrm{Ap}_{4} \mathrm{~A}$ and $\mathrm{Ap}_{3} \mathrm{~A}$ on epithelial cell migration is shown.

To understand the role that MAPK and actin cytoskeleton pathways have on rabbit corneal epithelial cell migration triggered by $\mathrm{Ap}_{4} \mathrm{~A}$ or $\mathrm{Ap}_{3} \mathrm{~A}$, we tested several inhibitors of both pathways. Wounded cells were preincubated for 30 minutes in the presence of the indicated inhibitor, and then were incubated for 2 minutes with the corresponding agonist, as described in the Methods section.

In SIRC cells, the preincubation with U0126 and AG1478, before $\mathrm{Ap}_{4} \mathrm{~A}$ application, produced a delay in cell migration (with a reduction in EMR). U0126 delayed EMR and increased

TABLE 1. EMRs and $\Delta$ EHTs for $\mathrm{Ap}_{4} \mathrm{~A}$ and $\mathrm{Ap}_{3} \mathrm{~A} 100 \mu \mathrm{M}$ in Wound Healing in the Presence of Antagonists in SIRC Cells

\begin{tabular}{|c|c|c|}
\hline Compound & EMR (\%) & $\Delta$ EHT (h) \\
\hline Control & $3.28 \pm 0.27$ & +8 \\
\hline Ap4A $100 \mu \mathrm{M}$ & $4.35 \pm 0.11^{\text {**** }}$ & 0 \\
\hline U0126+Ap4A $100 \mu \mathrm{M}$ & $2.52 \pm 0.32^{\text {**** }}$ & +12 \\
\hline AG1478+Ap4A $100 \mu \mathrm{M}$ & $2.20 \pm 0.19^{\text {***** }}$ & +26 \\
\hline Y27632 $100 \mathrm{nM}+\mathrm{Ap} 4 \mathrm{~A} 100 \mu \mathrm{M}$ & $3.21 \pm 0.68^{* *}$ & +6 \\
\hline (-)-Blebbistatin $10 \mu \mathrm{M}+\mathrm{Ap} 4 \mathrm{~A} 100 \mu \mathrm{M}$ & $2.51 \pm 1.0^{*}$ & +12 \\
\hline Ap3A $100 \mu \mathrm{M}$ & $2.98 \pm 0.17^{* * * *}$ & 0 \\
\hline U0126+Ap3A $100 \mu \mathrm{M}$ & $3.35 \pm 0.42$ & -4 \\
\hline AG1478+Ap3A $100 \mu \mathrm{M}$ & $2.71 \pm 0.31$ & +8.5 \\
\hline Y27632 $100 \mathrm{nM}+\mathrm{Ap} 3 \mathrm{~A} 100 \mu \mathrm{M}$ & $3.69 \pm 0.61$ & -6 \\
\hline (-)-Blebbistatin $10 \mu \mathrm{M}+\mathrm{Ap} 3 \mathrm{~A} 100 \mu \mathrm{M}$ & $1.51 \pm 0.35^{* * * *}$ & +10.5 \\
\hline
\end{tabular}

Data are the mean \pm SEM of eight independent experiments. + , delay induced by $\mathrm{Ap}_{4} \mathrm{~A}$ or $\mathrm{Ap}_{3} \mathrm{~A} 100 \mu \mathrm{M}$ compared with the control; -, acceleration compared with the same control data.

${ }^{* * *} P<0.0001,{ }^{* *} P<0.01,{ }^{*} P=<0.1$ vs. $\mathrm{Ap}_{4} \mathrm{~A}$ or $\mathrm{Ap}_{3} \mathrm{~A}$ alone. 
TABLE 2. EMRs and $\triangle \mathrm{EHTs}$ for $\mathrm{Ap}_{4} \mathrm{~A}$ and $\mathrm{Ap}_{3} \mathrm{~A} 100 \mu \mathrm{M}$ in Wound Healing in the Presence of Antagonists in Primary Culture Cells

\begin{tabular}{|c|c|c|}
\hline Compound & EMR (\%) & $\Delta$ EHT (h) \\
\hline Control & $4.20 \pm 0.15$ & +5 \\
\hline Ap4A $100 \mu \mathrm{M}$ & $6.25 \pm 0.33^{\text {***** }}$ & 0 \\
\hline U0126+Ap4A $100 \mu \mathrm{M}$ & $3.62 \pm 0.42^{* * * *}$ & +12 \\
\hline AG1478+Ap4A $100 \mu \mathrm{M}$ & $3.16 \pm 0.09^{* * * *}$ & +26 \\
\hline Y27632 $100 \mathrm{nM}+\mathrm{Ap} 4 \mathrm{~A} 100 \mu \mathrm{M}$ & $4.62 \pm 0.62^{* * *}$ & +6 \\
\hline (-)-Blebbistatin $10 \mu \mathrm{M}+$ Ap4A $100 \mu \mathrm{M}$ & $3.62 \pm 1.2^{*}$ & +12 \\
\hline Ap3A $100 \mu \mathrm{M}$ & $3.83 \pm 0.18^{* * * * *}$ & 0 \\
\hline U0126+Ap3A $100 \mu \mathrm{M}$ & $4.31 \pm 0.47$ & -4 \\
\hline AG1478+Ap3A $100 \mu \mathrm{M}$ & $3.48 \pm 0.22$ & +8.5 \\
\hline Y27632 $100 \mathrm{nM}+\mathrm{Ap} 3 \mathrm{~A} 100 \mu \mathrm{M}$ & $4.75 \pm 0.51$ & -6 \\
\hline (-)-Blebbistatin $10 \mu \mathrm{M}+\mathrm{Ap} 3 \mathrm{~A} 100 \mu \mathrm{M}$ & $1.94 \pm 0.31^{* * * *}$ & +10.5 \\
\hline
\end{tabular}

Data are the mean \pm SEM of eight independent experiments. + , delay induced by $\mathrm{Ap}_{4} \mathrm{~A}$ and $\mathrm{Ap}_{3} \mathrm{~A} 100 \mu \mathrm{M}$ compared with the control; - , acceleration compared with the same control values.

${ }^{* * * *} P<0.0001,{ }^{* *} P<0.01,{ }^{*} P<0.1$ vs. $\mathrm{Ap}_{4} \mathrm{~A}$ and $\mathrm{Ap}_{3} \mathrm{~A}$ alone.
EHT by 12 hours $(P=0.0002)$, and AG1478 reduced EMR with a delay in EHT of 26 hours, both statistically significant when compared with $\mathrm{Ap}_{4} \mathrm{~A}$ alone (Fig. 2A, Table 1). When we assayed the inhibitors of actin cytoskeleton pathway in the presence of $\mathrm{Ap}_{4} \mathrm{~A}$, we observed that both Y27632 and (-)-blebbistatin produced a statistically significant delay in EMR with an increased in EHT (6 hours for Y27632 and 12 hours for (-)blebbistatin; Fig. 2B, Table 1).

In accordance with our previous work, $\mathrm{Ap}_{3} \mathrm{~A}$ delayed EMR, and the preincubation with U0126 in the presence of this dinucleotide produced an acceleration in EMR with a decrease in EHT of 3 hours when compared with $A_{3} A$ alone. The preincubation with AG1478 produced a long delay in the migration rate, increasing the EHT 8.5 hours (Fig. 2C, Table 1). The preincubation with the different inhibitors for actin cytoskeleton, produced two different behaviors in the migration rate: (1) Y27632 produced an increase in EMR with a decrease in EHT of 6 hours when compared with $\mathrm{Ap}_{3} \mathrm{~A}$ alone, and (2)
A

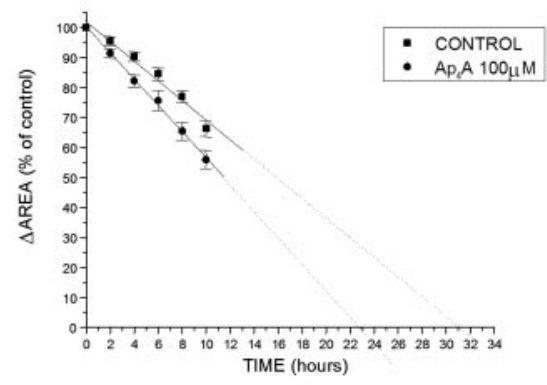

B
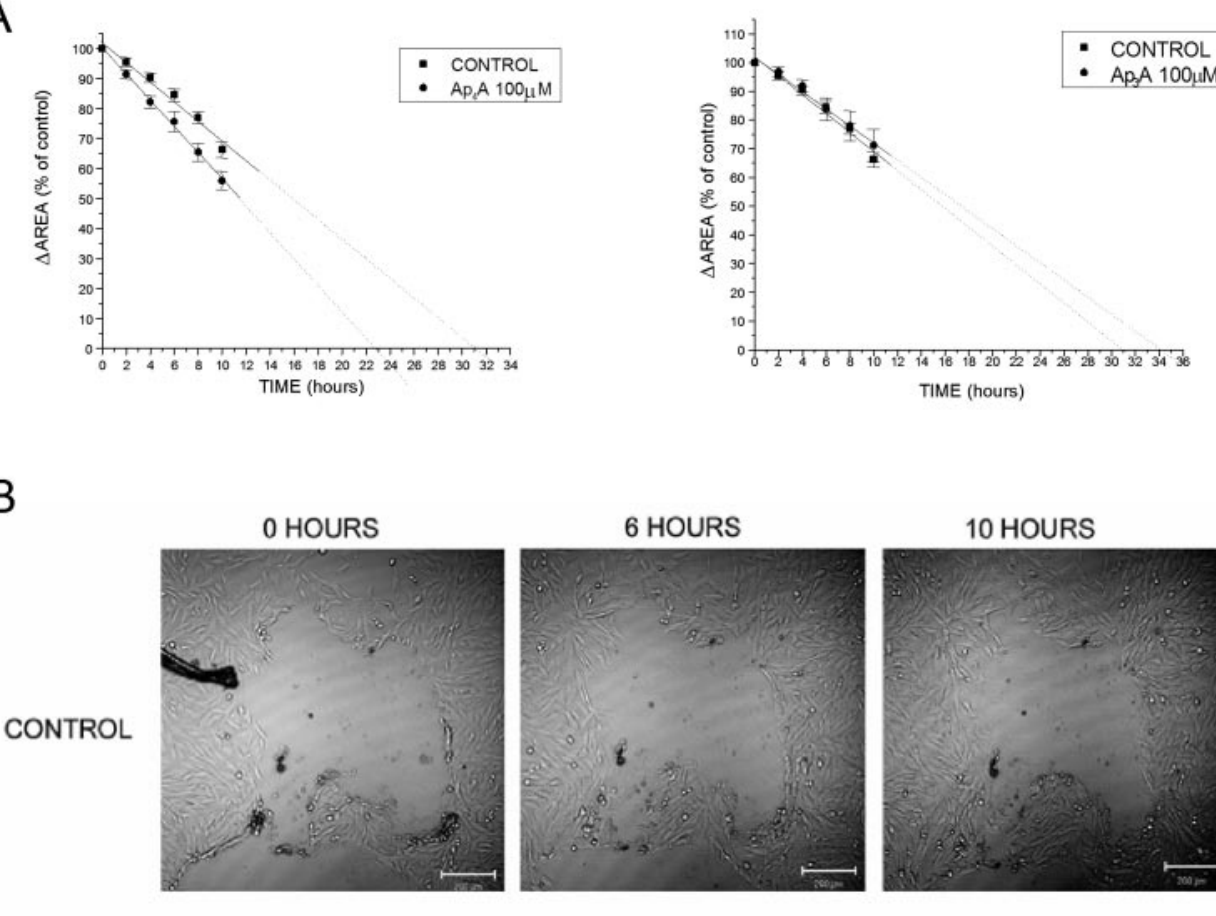

TIME (hours)
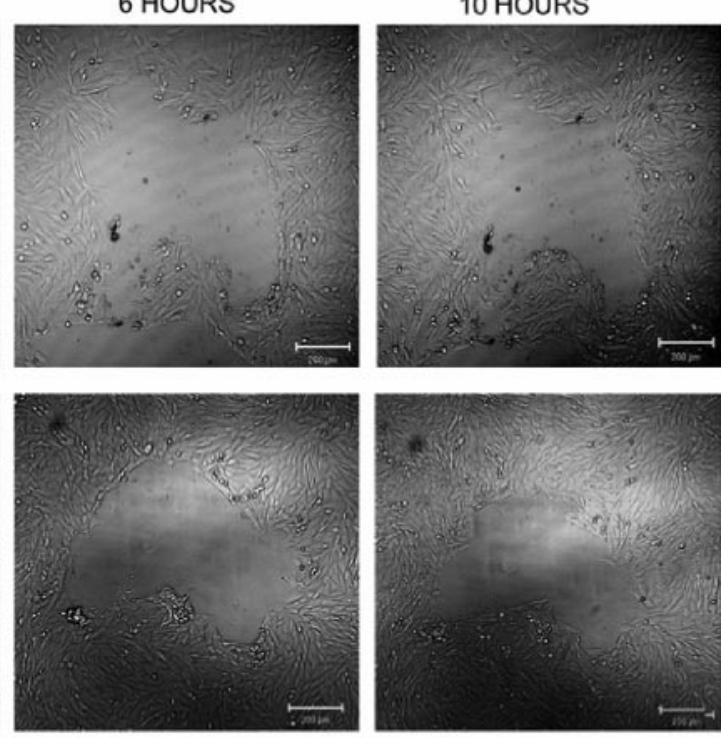

Ap4A
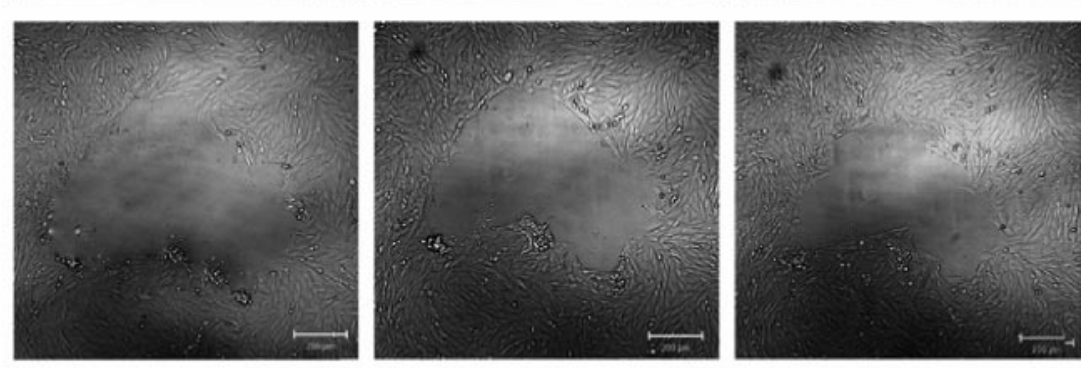

FigURE 1. Effects of $A p_{4} A$ and $A p_{4} A$ on SIRC cell migration. (A) The variation of the wounded area versus time after the protocol. (B) A series of micrographs allows comparison of the migration process in control conditions and after $\mathrm{Ap}_{4} \mathrm{~A}$ and $\mathrm{Ap}_{3} \mathrm{~A}, 100$ $\mu \mathrm{M}$ each, on cultured cell monolayers. The images were obtained at 0 , 6 , and 10 hours in the absence (control) or presence of the dinucleotides.
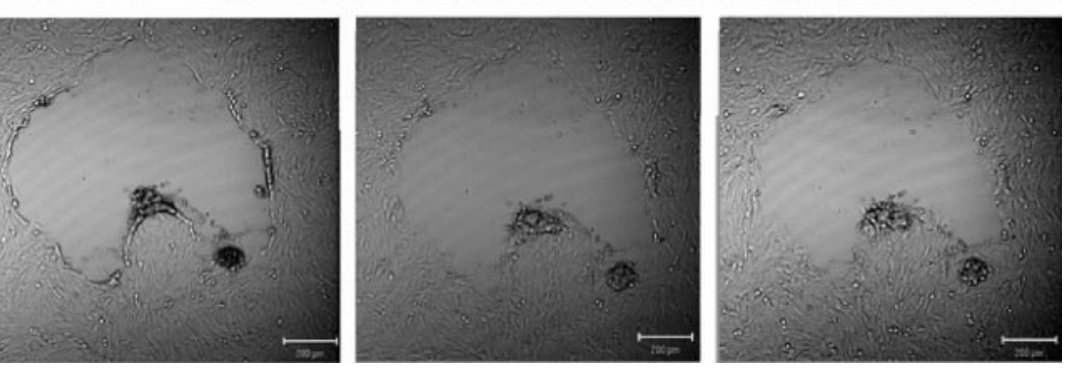
A

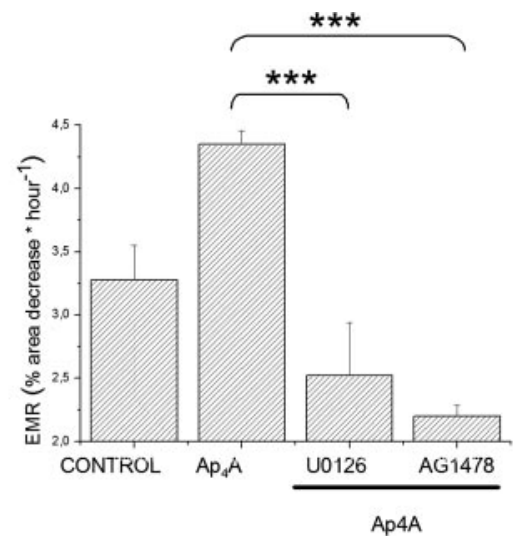

C

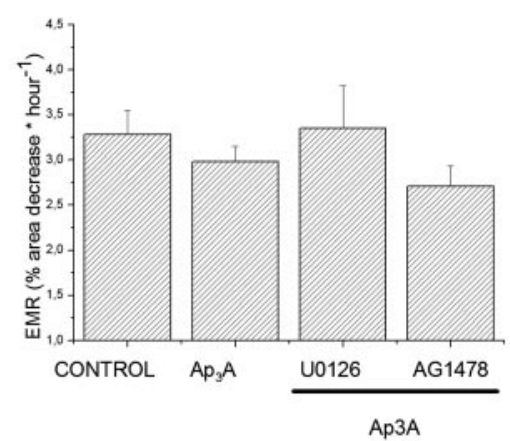

E

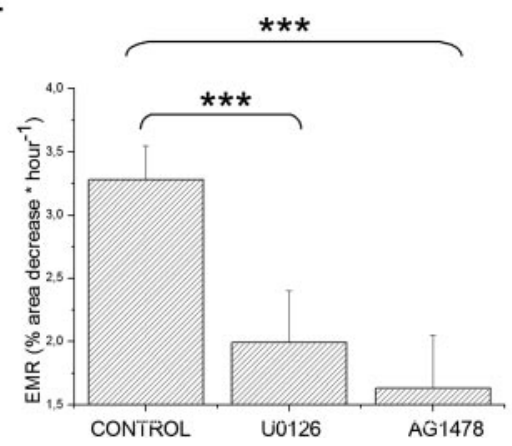

B

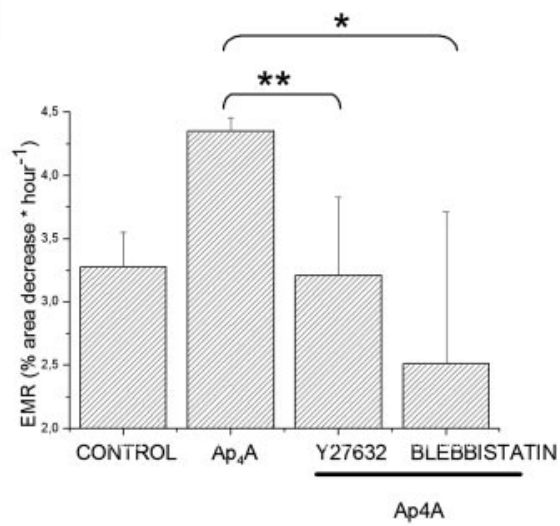

D

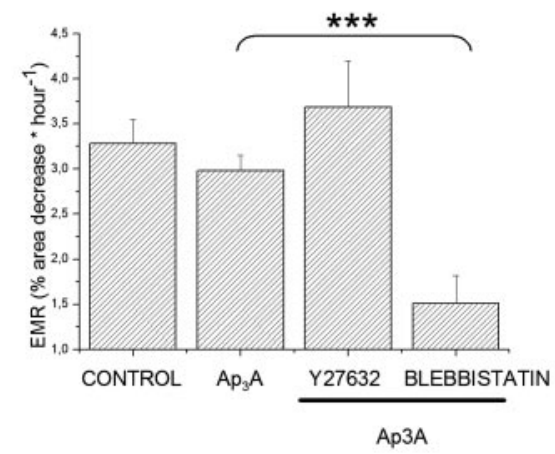

$\mathrm{F}$

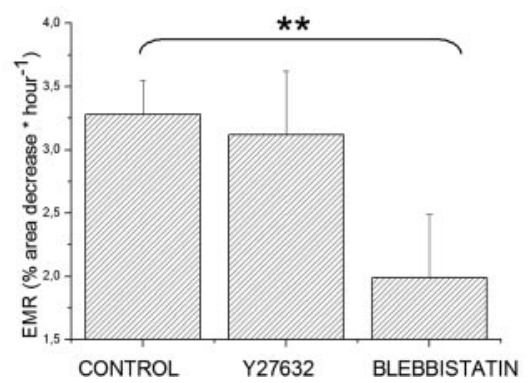

Figure 2. Effect of MAPK and cytoskeleton inhibitors on the rate of migration of corneal cells. (A) Change in EMR ( $\triangle \mathrm{EMR})$ when the inhibitors U0126 and AG1478 were tested with $\mathrm{Ap}_{4} \mathrm{~A}$, both at $100 \mu \mathrm{M}$. (B) Effect of Y27632 and (-)-blebbistatin on the $\mathrm{Ap}_{4} \mathrm{~A}$ rate of migration. (C) Effect of U0126 and AG1478 on $\mathrm{Ap}_{3} \mathrm{~A}$-induced migration delay. (D) Effect of Y27632 and (-)-blebbistatin on $\mathrm{Ap}_{3} \mathrm{~A}$-induced migration. $(\mathbf{E}, \mathbf{F})$ Effect of the four inhibitors in the absence of any dinucleotide. ${ }^{* * * *} P<0.0001,{ }^{* *} P<0.01,{ }^{*} P \leq 0.1$ vs. $\mathrm{Ap}_{4} \mathrm{~A}$ or $\mathrm{Ap}_{3} \mathrm{~A}$ alone. (-)-blebbistatin produced a statistically significant delay in EMR with an increase in EHT of 10.5 hours (Fig. 2D, Table 1).

When we tested the four inhibitors alone, U0126 $100 \mu \mathrm{M}$, AG1478, Y27632, and (-)-blebbistatin delayed the migration rate in a statistically significant manner: $1.9 \% \pm 0.42 \%, 1.63 \% \pm$ $0.41 \%, 3.12 \% \pm 0.50 \%$, and $1.99 \% \pm 0.50 \%$, respectively (control $3.28 \% \pm 0.27 \%$ ). Concomitantly, the estimated healing time increased 11 hours for U0126, 13 hours for AG1478, 1 hour for Y27632, and 20 hours for (-)-blebbistatin; Figs. 2E, 2F).

When migration assays were performed in primary culture cells, similar results were obtained (Table 2).

\section{Activation of MAPK and Actin Cytoskeleton Pathways}

To confirm the activation of the intracellular pathways previously studied in the migration assays, we analyzed pERK1/2 and ROCK-I by Western blot. These experiments were performed on wounded SIRC monolayers after treatments with $A p_{4} A$ or $A p_{3} A$, with or without antagonists of $\mathrm{P} 2 \mathrm{Y}$ receptors or
MAPK and RhoA/ROCK inhibitors, as described in the Methods section.

When we studied the activation of pERK1/2 in wounded epithelial cells in the presence of $A p_{4} A$ or $A p_{3} A$, we observed that $\mathrm{Ap}_{4} \mathrm{~A}$ promoted a rapid ( 5 minutes) and sustained activation of pERK1/2, with a maximum of activation at 1 hour $\left(28.71 \% \pm 1.48 \%\right.$ above control). In the case of $A_{3} A$, the pERK $1 / 2$ activation also reached maximum activation at 1 hour $(13.03 \% \pm 1.22 \%$ above control levels; results not shown).

ROCK-I was activated after incubation with $\mathrm{Ap}_{4} \mathrm{~A}$ presenting a maximum of activation of $10.05 \% \pm 0.90 \% 15$ minutes after the application of the dinucleotide. When we tested ROCK-I activation in the presence of $\mathrm{Ap}_{3} \mathrm{~A}$ in wounded monolayers, we observed a minimal increased 30 minutes after the application of this dinucleotide $(3.24 \% \pm 0.92 \%$; results not shown).

After setting the conditions for ERK1/2 and ROCK-I, we performed pERK1/2 and ROCK-I activation assays in the presence of $\mathrm{Ap}_{4} \mathrm{~A}$ or $\mathrm{Ap}_{3} \mathrm{~A}$, with several antagonists of the puriner- 
A
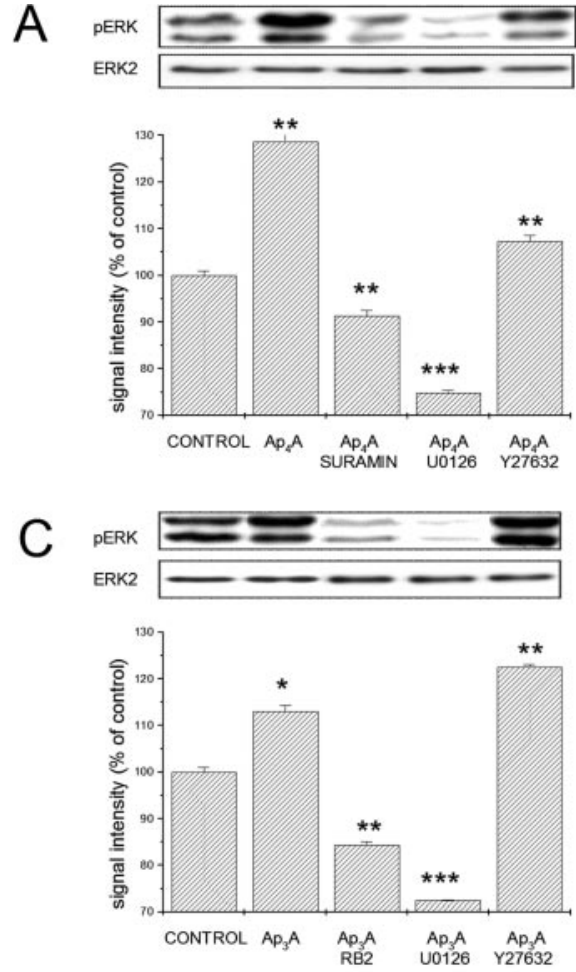

$E$

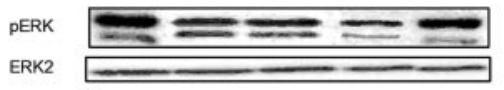

ERK2

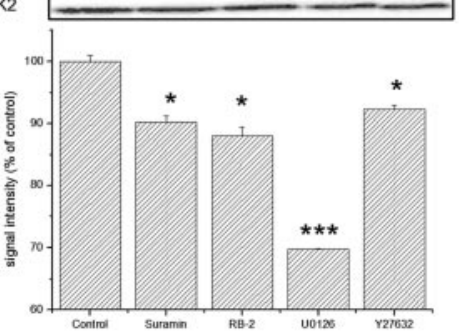

FIGURE 3. pERK1/2, ROCK, and pMLC2 activation in the presence of $\mathrm{Ap}_{4} \mathrm{~A}$ or $\mathrm{Ap}_{3} \mathrm{~A} 100 \mu \mathrm{M}$ with antagonists. (A) Activation of pERK1/2 by $\mathrm{Ap}_{4} \mathrm{~A} 100 \mu \mathrm{M}$ in the presence of suramin, U0126, and Y27632. (B) Effect of suramin, U0126, and Y27632 $100 \mu \mathrm{M}$ on the activation of ROCK-I after $\mathrm{Ap}_{4} \mathrm{~A}$ treatment. (C) Activation of pERK by $\mathrm{Ap}_{3} \mathrm{~A} 100 \mu \mathrm{M}$ in the presence of RB-2, U0126, and Y27632. (D) Activation of ROCK-I after preincubation with RB-2, U0126, and Y27632 in the presence of $\mathrm{Ap}_{3} \mathrm{~A} 100$ $\mu \mathrm{M}$. (E) Activation of ERK1/2 by suramin, RB-2, U0126, and Y27632 in the absence of any dinucleotide. (F) Effect of the antagonists alone on the activation of ROCK-I. (G) Effect of $\mathrm{Ap}_{4} \mathrm{~A}$ and $\mathrm{Ap}_{3} \mathrm{~A}$ alone and in the presence of Y27632 in the activation of pMLC2 $\left({ }^{* * *} P<0.0005,{ }^{* *} P<0.01\right.$, ${ }^{*} P \leq 0.1$ vs. $\mathrm{Ap}_{4} \mathrm{~A}$ or $\mathrm{Ap}_{3} \mathrm{~A}$ alone.
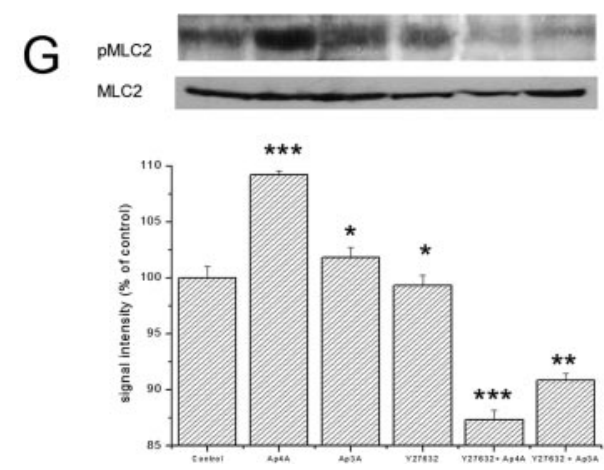
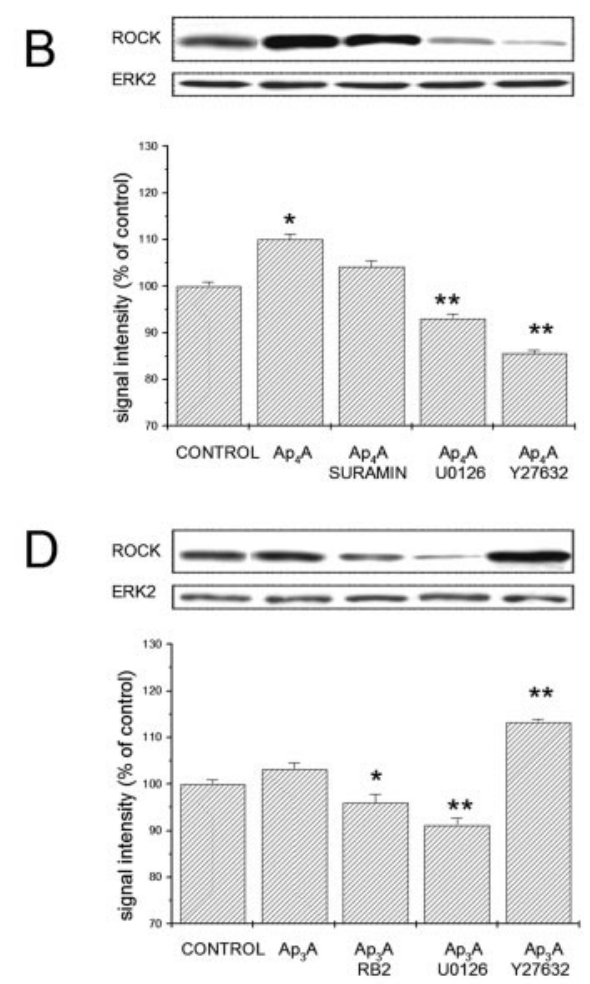

$\mathrm{F}$

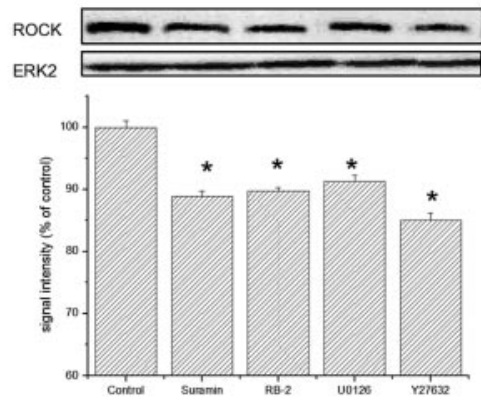

gic receptors MAPK and Rho/ROCK, according to the protocol described in the Methods section.

When we studied the activation of ERK1/2 by $\mathrm{Ap}_{4} \mathrm{~A}$ alone, we observed a statistically significant increase in phosphorylation $(128.71 \pm 1.48)$ when compared with the control in the absence of any added dinucleotide $(100 \% \pm 1.0 \%)$. In the presence of $\mathrm{Ap}_{4} \mathrm{~A}$, pretreatments with suramin, U0126, and Y27632, produced statistically significant increases in pERK1/2 activation: $91.35 \% \pm 1.18 \%, 74.97 \% \pm 0.42 \%$, and $107.29 \% \pm$ $1.33 \%$, respectively (Fig. 3A). When we tested how these three antagonists affected the activation of ROCK-I, when compared with $\mathrm{Ap}_{4} \mathrm{~A}$ alone $(110.05 \pm 0.90 \%)$, we observed that the three antagonists reduced ROCK-I activation in a statistically significant manner, the values being $104.19 \% \pm 2.89 \%$ for suramin, $93.11 \% \pm 0.98 \%$ for U0126, and $85.56 \% \pm 0.19 \%$ for $\mathrm{Y} 27632$ (Fig. 3B).

The same experiments were performed for $\mathrm{Ap}_{3} \mathrm{~A}$. This dinucleotide alone produced a statistically significant increase in pERK $1 / 2$ of $113.03 \% \pm 1.22 \%$, and pretreatments with RB-2 and U0126 produced a statistically significant reduction in ERK1/2 phosphorylation of $84.41 \% \pm 0.58 \%$ and $72.47 \% \pm$ $0.18 \%$, respectively. When the compound Y27632 was tested, 
a statistically significant increase in pERK1/2 (122.63\% \pm $0.39 \%$ ) was observed (Fig. 3C). As presented in Figure 3D, there was a reduction in ROCK-I activation after pretreatment with RB-2 and U0126, the values being $95.97 \% \pm 3.24 \%$ and $91.20 \% \pm 0.78 \%$, respectively, when compared with $\mathrm{Ap}_{3} \mathrm{~A}$ alone $(103.24 \% \pm 0.92 \%)$, with these differences being statistically significant. The pretreatment with Y27632 produced an increase in the activation of ROCK-I $(113.35 \% \pm 0.33 \%)$.

When we tested the activation of both ERK1/2 and ROCK-I in the presence of the antagonists alone, we observed that suramin, RB-2, U0126, and Y27632 produced a statistically significant decrease in pERK1/2 phosphorylation $(9.77 \% \pm$ $1.0 \%$ for suramin, $11.98 \% \pm 1.47 \%$ for RB-2, $30.2 \% \pm 0.16 \%$ for U0126, and $7.69 \% \pm 0.70 \%$ for Y27632; Fig. 3E). When ROCK-I activation was analyzed, the four antagonists produced a similar effect $(11.14 \% \pm 0.86 \%$ for Suramin, $10.27 \% \pm 0.54 \%$ for RB-2, 8.78\% $\pm 1.08 \%$ for U0126, and $14.99 \% \pm 1.28 \%$ for Y27632; Fig. 3F).

Rho/ROCK pathway involvement was further confirmed with the study of the activation of myosin light chain kinase 2 phosphorylation (pMLC2), since this protein is downstream of Rho/ROCK in this canonical intracellular pathway. Therefore, Figure $3 G$ shows the phosphorylation of this protein after treatments with $\mathrm{Ap}_{4} \mathrm{~A}, \mathrm{Ap}_{3} \mathrm{~A}, \mathrm{Y} 27632, \mathrm{Ap}_{4} \mathrm{~A} / \mathrm{Y} 27632$, and $\mathrm{Ap}_{3} \mathrm{~A} / \mathrm{Y} 27632$. $A \mathrm{p}_{4} \mathrm{~A}$ produced a statistically significant increase in pMLC2 of $109.16 \% \pm 0.41 \%$, compared with the control, which was reversed with the preincubation with the antagonist to ROCK-I Y27632 (87.34\% $\pm 0.84 \%)$, whereas there was no increase in pMLC2 activation with $\mathrm{Ap}_{3} \mathrm{~A}(101.82 \%$ $\pm 0.91 \%$, Fig. 3G).

\section{Immunocytochemistry for PERK and ROCK}

There were unexpected actions of some of the MAPK inhibitors, such as U0126 acting on the ROCK-I pathway and vice versa (Y27632 on the pERK pathway). To explain such apparently unpredictable results, we investigated whether both pathways are connected. In this sense, we investigated the cellular distribution of pERK1/2 after treatment with $\mathrm{Ap}_{4} \mathrm{~A}$ and $\mathrm{Ap}_{4} \mathrm{~A}$ with Y27632. In the absence of any added compound (control condition), pERK was mainly localized in the cytoplasm with no colocalization detected with the green nuclear dye, which means that in control situations, pERK was not translocated to the nucleus. pERK1/2 activation by $A_{4} \mathrm{~A}_{4}$ was distributed in a uniform pattern, with a good colocalization with the nuclear marker, which means that it was in part translocated to the nucleus, as indicated in another study. ${ }^{41}$ When $\mathrm{Ap}_{4} \mathrm{~A}$ and Y27632 were combined, we observed that pERK1/2 staining was mainly located in the cytoplasm, with less staining in the nucleus, as revealed by less colocalization with the green nuclear marker (Fig. 4A). Figure $4 \mathrm{~B}$ shows the pERK signal quantification in the cytoplasm and in the nucleus of control cells and cells treated with $\mathrm{Ap}_{4} \mathrm{~A}$ and $\mathrm{Ap}_{4} \mathrm{~A} / \mathrm{Y} 27632$. As we observed, the amount of pERK in the cytoplasm of $\mathrm{Ap}_{4} \mathrm{~A}$ was higher than in the cytoplasm of $\mathrm{Ap}_{4} \mathrm{~A} / \mathrm{Y} 27632$ cells (1151.91 \pm 7.26 and $1046.78 \pm 9.97$. respectively), and the amount of pERK in the cytoplasm of control cells was the lowest $(861.64 \pm 13.31)$. The same occurred with the nucleus, with the control having less signal for pERK (3095.42 \pm 7.19 for $\mathrm{Ap}_{4} \mathrm{~A}, 1871.27 \pm 9.35$ for $\mathrm{Ap}_{4} \mathrm{~A} / \mathrm{Y} 27632$, and $328.56 \pm$ $7.15, P<0.0001$ ), which is consistent with less colocalization of the green dye and with less translocation of pERK to the nucleus. All differences are statistically significant.

When we performed the immunocytochemical staining for ROCK-I alone, after $\mathrm{Ap}_{4} \mathrm{~A}$, and after $\mathrm{Ap}_{4} \mathrm{~A}$ with $\mathrm{U} 0126$ (Fig. 4C), we observed that ROCK-I stained the whole cytoplasm of the cells in all three cases, without colocalizing with the nuclear staining in any of them. Ap ${ }_{4} \mathrm{~A}$-treated cells presented more staining for ROCK-I than in any of the other assays. ROCK-I staining for $\mathrm{Ap}_{4} \mathrm{~A}$ in the presence of U0126 was less intense than that for $\mathrm{Ap}_{4} \mathrm{~A}$ alone. When we quantified the ROCK-I signal in the cytoplasm and in the nucleus (Fig. 4D), we observed that the signal in the cytoplasm of the $A_{4}{ }_{4} \mathrm{~A}$-challenged cells was more robust $(1038.77 \pm 15.35)$ than in the cytoplasm of $\mathrm{Ap}_{4} \mathrm{~A} / \mathrm{U} 0126$-treated cells $(907.78 \pm 10.92)$, and that in the control cells, the signal was intermediate $(983.86 \pm$ 6.17). The same occurred with the amount of ROCK-I in the nucleus. In $\mathrm{Ap}_{4} \mathrm{~A} / \mathrm{U} 0126$-treated cells, signaling for ROCK-I was less intense $(860.81 \pm 10.01)$ than in the nucleus of $\mathrm{Ap}_{4} \mathrm{~A}$ challenged cells $(1219.52 \pm 11.96)$, with the nucleus showing the least intense signal of all $(738.70 \pm 3.52)$. Again, all differences are statistically significant (Fig. 4, legend).

In the case of $\mathrm{Ap}_{3} \mathrm{~A}$, we observed that pERK1/2 staining after treatment with $A_{3} A$ and $A p_{3} A$ with Y27632, was distributed in a similar uniform pattern, with good colocalization with nuclear staining, which shows that it translocated to the nucleus (Fig. 4E). In control cells, pERK was mainly localized in the cytoplasm with no colocalization with the nuclear stain, which indicates that in control situations, pERK was not translocated to the nucleus (Fig. 4E). Figure $4 \mathrm{~F}$ revealed that the amount of pERK signal in $\mathrm{Ap}_{3} \mathrm{~A}$ challenged cell cytoplasm was very similar to that in $\mathrm{Ap}_{3} \mathrm{~A} /$ Y27632-treated cells $(988.11 \pm 9.43$ and $1017.00 \pm 6.7$, respectively), whereas in control cell cytoplasm, the amount was less $(861.64 \pm 13.31)$. In the nucleus the presence of p-ERK was significantly higher in both treatments $\left(2062.35 \pm 8.83\right.$ for $A_{3} A$, and $1777.82 \pm 5.77$ for $A_{3} A /$ Y27632) than the nucleus staining in control cells (328.56 \pm 7.15). All differences are statistically significant.

These results were confirmed by Western blot isolating the cytosolic and nuclear fractions separately (Fig. 5). Compared with the control experiment $(100 \% \pm 1.0 \%)$, cytosolic pERK signal was significantly increased in cells treated with $\mathrm{Ap}_{4} \mathrm{~A}$ $(120.25 \% \pm 1.37 \%)$ and in those treated with $\mathrm{Ap}_{4} \mathrm{~A} / \mathrm{Y} 27632$ $(108.72 \% \pm 1.59 \%)$. Nuclear pERK signaling was also significantly increased in relation to signaling in control nuclei $\left(114.90 \% \pm 1.46 \%\right.$ for $\mathrm{Ap}_{4} \mathrm{~A}$ and $102.90 \% \pm 1.70 \%$ for $\mathrm{Ap}_{4} \mathrm{~A} /$ Y27632; Fig. 5A). As observed, the treatment with Y27632 produced a strong, statistically significant decrease in pERK translocation to the nucleus in relation to pERK signal in cells treated with $\mathrm{Ap}_{4} \mathrm{~A}$ alone.

In the case of ROCK-I, treatment with $\mathrm{Ap}_{4} \mathrm{~A}$ produced a statistically significant increase in signaling for ROCK-I in the cytoplasm $(108.63 \% \pm 0.61 \%)$ compared with the control experiment $(100 \% \pm 1.0 \%)$, whereas treatment with $\mathrm{Ap}_{4} \mathrm{~A} /$ U0126 did not affect ROCK-I activation (100.68\% $\pm 0.54 \%)$. The nuclear ROCK-I signaling, was not altered in $\mathrm{Ap}_{4} \mathrm{~A}$-treated cells $(101.24 \% \pm 1.40 \%)$, whereas in $\mathrm{Ap}_{4} \mathrm{~A} / \mathrm{U} 0126$ treated cells, nuclear ROCK signaling decreased significantly $(88.77 \% \pm$ $1.18 \%)$ when compared with the level in the control $(100 \% \pm$ 1.0\%; Fig. 5B).

\section{Discussion}

The present experimental work describes how $\mathrm{Ap}_{4} \mathrm{~A}$ activates two intracellular pathways, ERK and ROCK-I, to permit corneal cell migration. One of the questions that arise from the migration assays is whether the rabbit immortalized cell line used work behaves similarly to primary cells obtained from rabbit cornea. The migration behavior after treatment with $\mathrm{Ap}_{4} \mathrm{~A}$ and $\mathrm{Ap}_{3} \mathrm{~A}$ in the immortalized cell line and the primary cultures was almost identical; therefore, we performed all the subsequent experimental procedures on the immortalized cell line. The results showed that the blockade of both pathways by means of the corresponding inhibitors significantly reduced the ability 


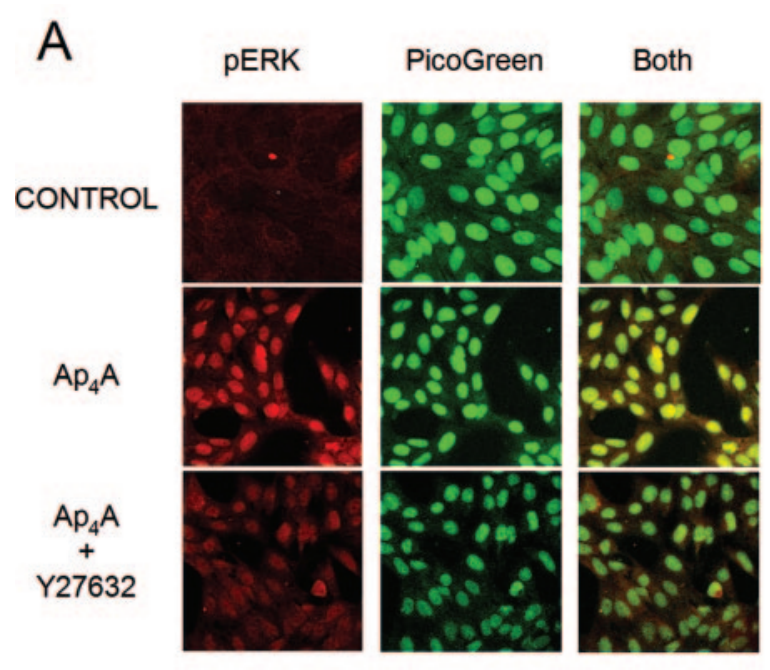

B
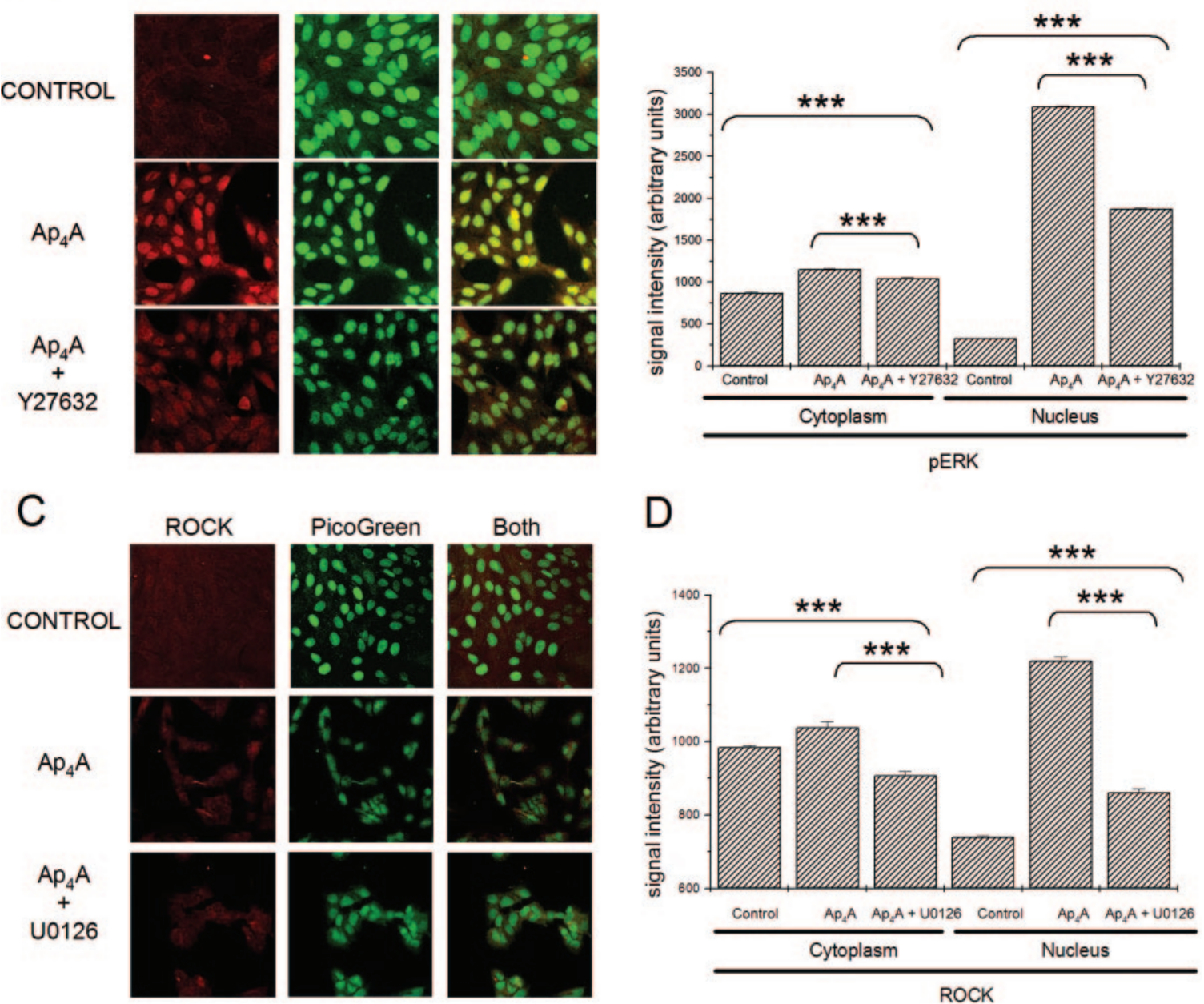

$\mathrm{D}$
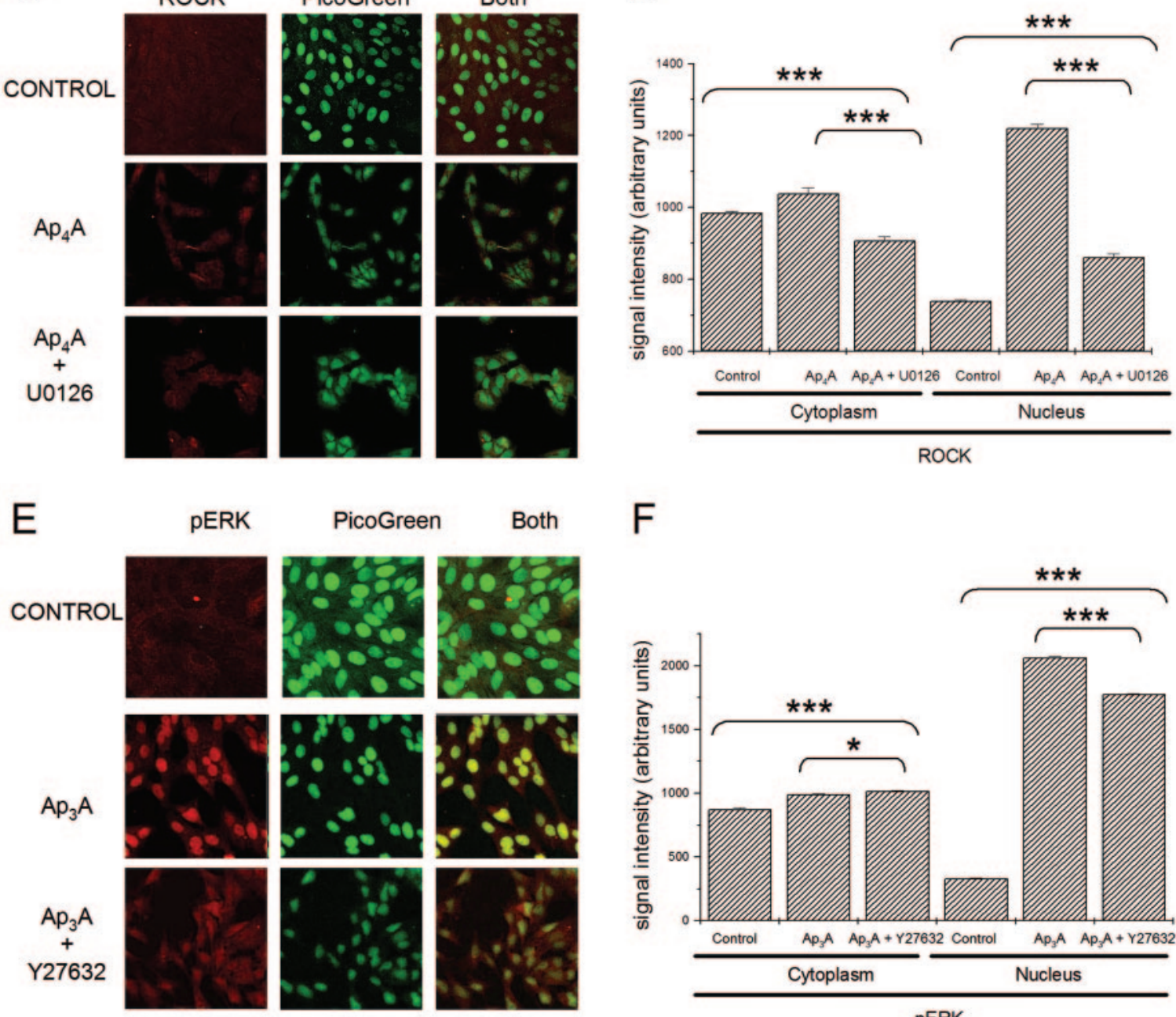

$\mathrm{F}$
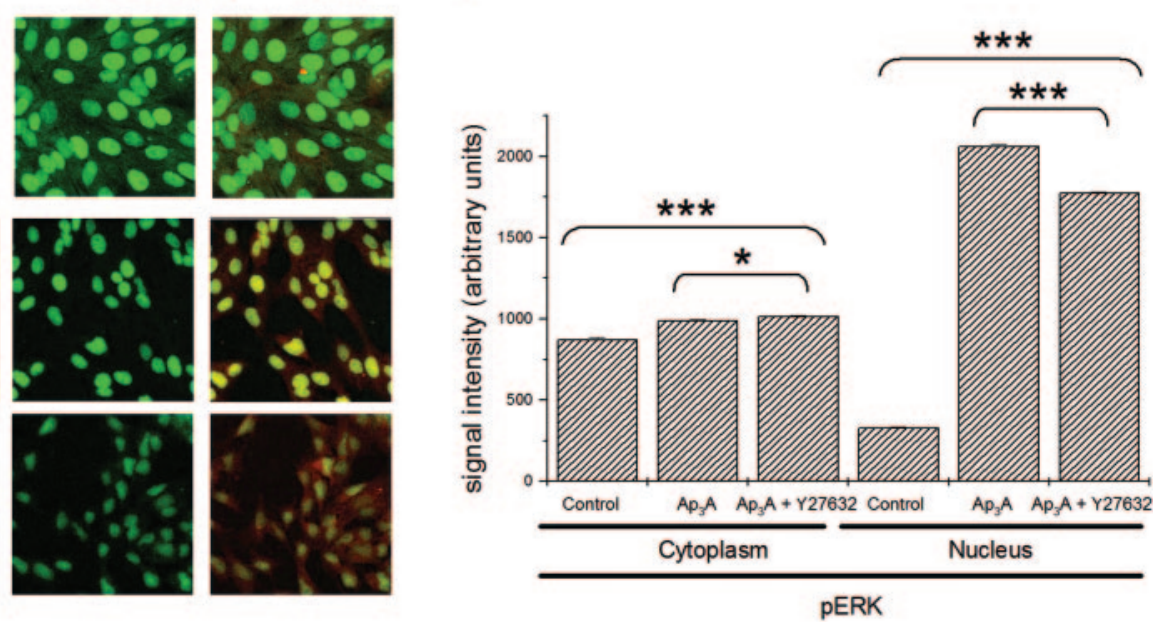

FIGURE 4. Cellular distribution of pERK1/2 and ROCK after treatment with $\mathrm{Ap}_{4} \mathrm{~A}$ and Ap3A in the presence and absence of various inhibitors. (A) Immunocytochemical distribution of pERK signal in control cells and in the presence of $\mathrm{Ap}_{4} \mathrm{~A}$ and $\mathrm{Ap}_{4} \mathrm{~A}$ with Y27632, each 100 nM. Red: pERK1/2 signal; green: nuclear marker. (B) pERK signal quantification in the cytoplasm and nucleus of control cells and cells treated with $\mathrm{Ap}_{4} \mathrm{~A}$ and $\mathrm{Ap}_{4} \mathrm{~A} / \mathrm{Y} 27632,100 \mu \mathrm{M}$ and $100 \mathrm{nM}$, respectively. (C) Cellular distribution of ROCK-I in control cells and after Ap $\mathrm{Ap}_{4} \mathrm{~A}$ and $\mathrm{Ap}_{4} \mathrm{~A}$ with U0126, each $100 \mu$ M. Red: ROCK-I signal; green: nuclear marker. (D) Quantification of ROCK-I signal in the cytoplasm and in the nucleus of control, $\mathrm{Ap}_{4} \mathrm{~A}$, and $\mathrm{Ap}_{4} \mathrm{~A} / \mathrm{U} 0126$, each $100 \mu \mathrm{M}$. (E) Immunocytochemical distribution of pERK signal in control cells and after $\mathrm{Ap}_{3} \mathrm{~A}$ and $\mathrm{Ap}_{3} \mathrm{~A}$ with $\mathrm{Y27632}, 100 \mu \mathrm{M}$ and $100 \mathrm{nM}$, respectively. Red: pERK1/2 signal; green: nuclear marker. (F) pERK signal quantification in the cytoplasm and in the nucleus of cells treated with $\mathrm{Ap}_{3} \mathrm{~A}$ and $\mathrm{Ap}_{3} \mathrm{~A} / \mathrm{Y} 27632,100 \mu \mathrm{M}$ and $100 \mathrm{nM}$, respectively. ${ }^{* * * *} P<0.0001,{ }^{* * *} P<0.01,{ }^{*} P \leq 0.1$ vs. Ap ${ }_{3} \mathrm{~A}$ or $\mathrm{Ap}_{4} \mathrm{~A}$ alone. Magnification, $\times 40$. 
A

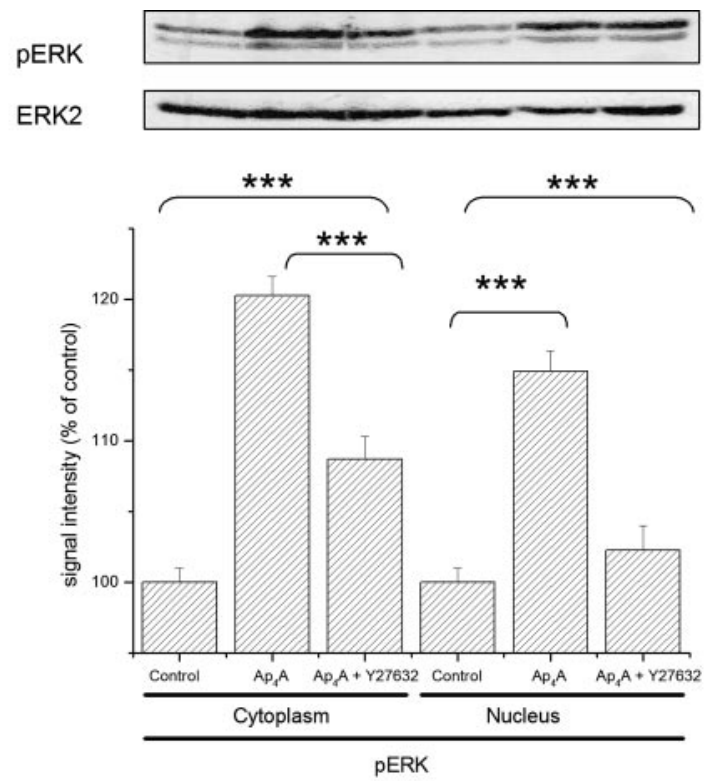

B

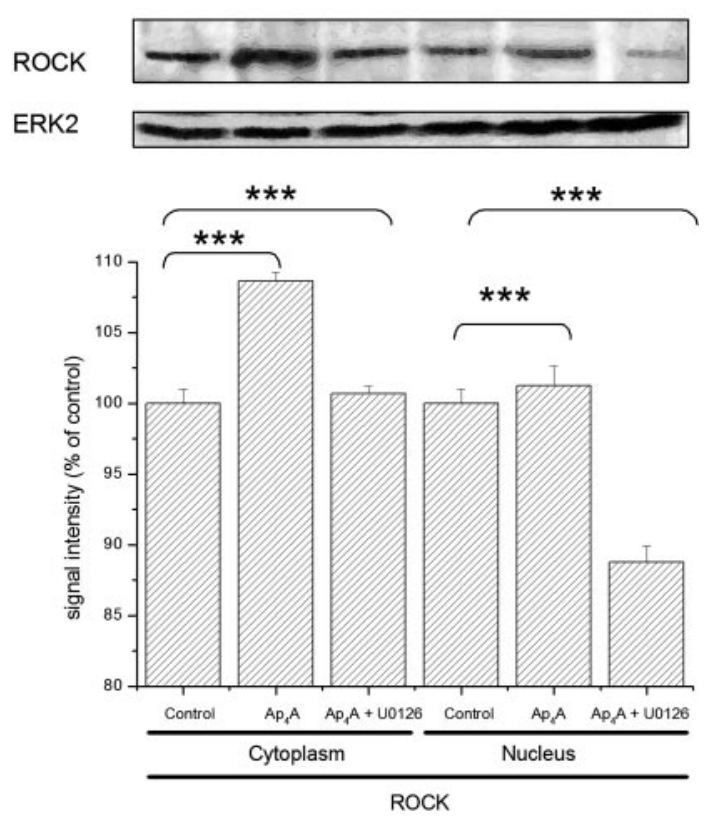

FIGURE 5. Western-blot analysis of the cellular distribution of pERK1/2 and ROCK signal after treatment with $\mathrm{Ap}_{4} \mathrm{~A}$ in the presence and absence of various inhibitors. (A) pERK activation in the cytoplasm of cells treated with $\mathrm{Ap}_{4} \mathrm{~A}$ and $\mathrm{Ap}_{4} \mathrm{~A}+\mathrm{Y} 27632$ and in absence of any added compound. (B) ROCK-I signal in the nuclear fraction of the treated cells. ${ }^{* * * *} P<0.0001,{ }^{* *} P<0.01,{ }^{*} P \leq 0.1$ vs. $\mathrm{Ap}_{4} \mathrm{~A}$ alone.

of $A p_{4} A$ to increase the rate of healing. In the case of $A p_{3} A$, since this compound delayed cell migration, a contrary effect was observed in the assay of these compounds.

The actions of $A p_{4} A$ and $A p_{3} A$ are triggered after stimulation of the $\mathrm{P} 2 \mathrm{Y}_{2}$ and $\mathrm{P} 2 \mathrm{Y}_{6}$ receptors, respectively, as previously described. ${ }^{23,42}$ This effect was confirmed by use of the selective $\mathrm{P} 2$ receptor antagonists.

It is reasonable to think that the increase in the migration rate induced by $\mathrm{Ap}_{4} \mathrm{~A}$ via $\mathrm{P}_{2} \mathrm{Y}_{2}$ receptors is linked to the activation of the RhoA/ROCK pathway. Indeed, it has been demonstrated that this pathway is linked to the actin cytoskeleton-changing cellular contractility. ${ }^{30}$ This possibility has been confirmed by using compounds that inhibiting this pathway, such as Y27632 and (-)-blebbistatin, which inhibit
ROCK-I and myosin light kinase phosphorylation, which significantly abolishes the pro-migratory effect of $\mathrm{Ap}_{4} \mathrm{~A}$. The same inhibition of cell migration can be obtained when the $\mathrm{P}_{2} \mathrm{Y}_{2}$ receptor stimulated by $\mathrm{Ap}_{4} \mathrm{~A}$ is antagonized with suramin, not only when studying cell migration ${ }^{23}$ but also when analyzing ROCK-I phosphorylation (Fig. 3B). In a previous work, we have demonstrated that migration in corneal wounds produced in rabbit corneas is blocked by the PKC inhibitor staurosporine. ${ }^{22}$ This suggests that $\mathrm{P} 2 \mathrm{Y}_{2}$ receptors can activate the classic PLC and $\mathrm{PKC}$ activation pathway and that this would be connected with RhoA/ROCK activation. In addition, the $\mathrm{P}_{2} \mathrm{Y}_{2}$ receptors present in corneal epithelial cells can activate the MAP kinase cascade, as was demonstrated in the present study. Indeed, $\mathrm{Ap}_{4} \mathrm{~A}$ also activated the $\mathrm{p} 42 / \mathrm{p} 44$ pathway. In this case, ${ }^{43}$ the tyrphostin AG1479 or the MEK inhibitor U0126 avoided the phosphorylation of ERK1/2. The involvement of this pathway has been demonstrated for $\mathrm{P}_{2} \mathrm{Y}_{2}$ receptors ${ }^{43-45}$ and suggests the transactivation of $\mathrm{P}_{2} \mathrm{Y}_{2}$ receptors with tyrosine kinase receptors such as the EGF receptor. ${ }^{22,32}$

It is important to note that both pathways seem to be activated simultaneously, and unexpectedly, the inhibitors of one of the cascades could modify the activity of the other. For example, Y27632 significantly reduced the phosphorylation of ERK1/2 triggered by Ap 4 A. Also U0126 reduced the phosphorylation of ROCK-I. Of note, when U0126 was assayed, migration was reduced below the control level; and also, when ROCK-I was analyzed, it presented expression levels that were below those of the control. This result suggests that the main pathway responsible for cell migration in corneal epithelial cells is the one in which RhoA/ROCK are involved. On the other hand, we cannot exclude ERK1/2's participation in the migration process; however, it seems to be plausible that the MAPK cascade is more involved in processes related to longterm effects, since ERK1/2 was translocated to the nucleus (Figs. 4, 5). Also, the relation between ERK and ROCK-I is so close that Y27632 hindered the translocation of p-ERK1/2 to the nucleus (Figs. 4, 5). The biochemical meaning of this cross-talk to be elucidated, and different and contradictory hypotheses have been described regarding the possible connection between pERK1/2 and ROCK-I pathways. ${ }^{41,46-48} \mathrm{Nev}$ ertheless, some ideas can be suggested. Corneal wound healing is a process divided in three steps: a lag phase (up to 8 hours after the wound happened), migration step (24-36 hours), and proliferation step (more than 36 hours until days). ${ }^{49}$ The latter implies the activation of some processes in which the translocation of p-ERK to the nucleus may be compulsory. It has been demonstrated that inhibition of ERK1/2 reduces the process of DNA synthesis and arrests the mitotic process. ${ }^{50}$ Indeed, ERK activation is necessary for $G_{2} / M$ transition, as indicated in another study, ${ }^{51}$ and so it would not be strange to think that the $\mathrm{P}_{2} \mathrm{Y}_{2}$ activation by $\mathrm{Ap}_{4} \mathrm{~A}$, which involves ERK1/2 activation, prepares epithelial cells for the mitotic step in the corneal wound-healing process (Fig. 6). More experiments are needed to confirm this hypothesis.

On the other hand, $\mathrm{Ap}_{3} \mathrm{~A}$ delayed the rate of healing, presumably by activating a $\mathrm{P} 2 \mathrm{Y}_{6}$ receptor as previously reported. ${ }^{23}$ $\mathrm{Ap}_{3} \mathrm{~A}$ action was reversed by the MEK inhibitor U0126 but was unaffected by AG1479, suggesting a different intracellular mechanism from the one of $\mathrm{Ap}_{4} \mathrm{~A}$. The effect of the RhoA/ ROCK cascade inhibitors was contradictory. On the one hand, the ROCK-I inhibitor enhanced migration (slightly but statistically significant), and on the other hand, the MLK inhibitor delayed the rate of healing even more. It would be expected that this pathway, in the presence of the inhibitors of the RhoA/ROCK cascade, would not change that the inhibition would be even more robust. These contradictory aspects suggest the participation of other mechanisms that are not well understood. In this sense, the confirmation of this inconsistent 


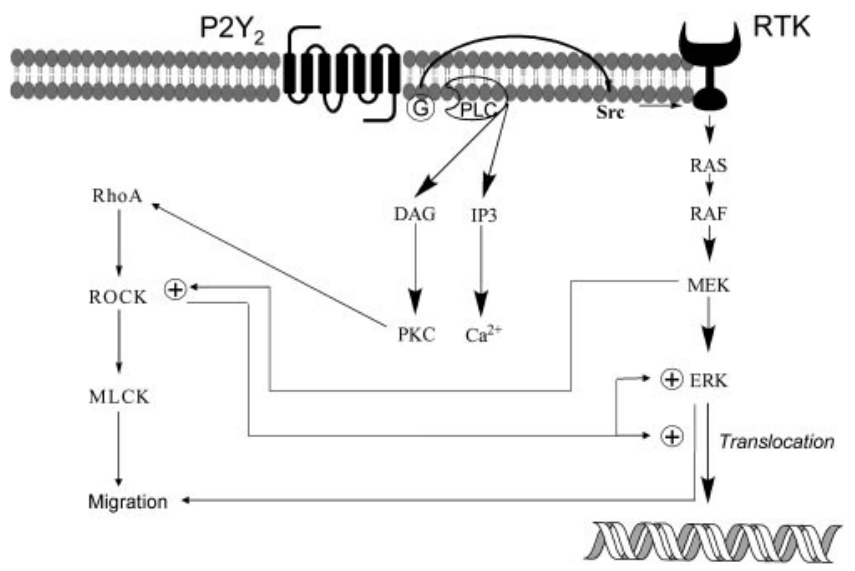

FIGURE 6. Cross-talk between MAPK and RhoA/ROCK pathways after $\mathrm{Ap}_{4} \mathrm{~A}$ activation of $\mathrm{P}_{2} \mathrm{Y}_{2}$ receptors, which produced the activation of both the RhoA/ROCK-I and MAPK cascades.

behavior also appears when ROCK-I is investigated. Y27632 increased the phosphorylation of this protein, in a result that was consistent with the migration studies. Again, other mechanisms controlling the behavior of ROCK-I may explain the delay produced by $\mathrm{Ap}_{3} \mathrm{~A}$.

Finally, we conclude that $A_{4} A$, via the activation of the $\mathrm{P}_{2} \mathrm{Y}_{2}$ receptor, activates both the MAPK and the RhoA/ROCK pathways, and both are necessary for the migration process, with ERK also involved in other long-term processes.

\section{Acknowledgments}

The authors thank Khairul Anwar for help in the preparation of the manuscript.

\section{References}

1. Burnstock $G$. The past, present and future of purine nucleotides as signalling molecules. Neuropharmacology. 1997;36(9):11271139.

2. McLennan AG. Dinucleoside polyphosphates: friend or foe? Pharmacol Ther. 2000;87(2-3):73-89.

3. Burnstock G, Knight GE. Cellular distribution and functions of P2 receptor subtypes in different systems. Int Rev Cytol. 2004;240: 301-304.

4. Rotllan P, Miras-Portugal MT. Adenosine kinase from bovine adrenal medulla. Eur J Biochem. 1985;151(2):365-371.

5. Hilderman RH, Christensen EF. P1, P4-diadenosine 5' tetraphosphate induces nitric oxide release from bovine aortic endothelial cells. FEBS Lett. 1998;427(3):320-324.

6. Zamecnik PC, Kim B, Gao MJ, Taylor G, Blackburn GM. Analogues of diadenosine $5^{\prime}, 5^{\prime \prime \prime}-\mathrm{P} 1$, P4-tetraphosphate (Ap4A) as potential anti-platelet-aggregation agents. Proc Natl Acad Sci USA. 1992; 89(6):2370-2373.

7. Pintor J, Diaz-Hernandez M, Gualix J, Gomez-Villafuertes R, Hernando F, Miras-Portugal MT. Diadenosine polyphosphate receptors: from rat and guinea-pig brain to human nervous system. Pharmacol Ther. 2000;87(2-3):103-115.

8. Burnstock G, Kennedy C. Is there a basis for distinguishing two types of P2-purinoceptor? Gen Pharmacol. 1985;16:433-440.

9. North RA. Molecular physiology of P2X receptors. Physiol Rev. 2002;82:1013-1067.

10. North RA. P2Y purinoceptor plethora. Semin Neurosci. 1996;8: 187-194.

11. Ralevic V, Burnstock G. Receptors for purines and pyrimidines. Pharmacol Rev. 1998;50:413-492.

12. Khakh BS. Molecular physiology of P2X receptors and ATP signalling at synapses. Nat Rev Neurosci. 2001;2:165-174.
13. Weisman GA, Gonzalez FA, Erb L, Garrad RA, Turner JT. The cloning and expression of G-coupled P2Y receptors. In: Turner JT, Weisman GA, Fedan JS, eds. The P2 Nucleotide Receptors. Totowa, NJ; Humana Press Inc., 1998:63-79.

14. Chambers JK, MacDonald LE, Sarau HM, et al. A G protein-coupled receptor for UDP-glucose. J Biol Chem. 2000;275(15):1076710771.

15. Zhang FL, Luo L, Gustafson E, et al. P2Y(13): identification and characterization of a novel Galphai-coupled ADP receptor from human and mouse. J Pharmacol Exp Ther. 2002;301(2):705-713.

16. Sak K, Webb TE. A retrospective of recombinant $\mathrm{P} 2 \mathrm{Y}$ receptor subtypes and their pharmacology. Arch Biochem Biophys. 2002; 397:131-136.

17. Boeynaems JM, Communi D, Gonzalez NS, Robaye B. Overview of the P2 receptors. Semin Thromb Hemost. 2005;31:139-149.

18. Boeynaems JM, van Giezen H, Savi P, Herbert JM. P2Y receptor antagonists in thrombosis. Curr Opin Investig Drug. 2005;6:275282.

19. Pintor J, Peral A, Peláez T, Carracedo G, Bautista A, Hoyle CHV. Nucleotides and dinucleotides in ocular physiology: new possibilities of nucleotides as therapeutic agents in the eye. Drug Develop Res. 2003;58:1-10.

20. Pintor J, Carracedo G, Alonso MC, Bautista A, Peral A. Presence of diadenosine polyphosphates in human tears. Pflugers Arch. 2002; 443(3):432- 436.

21. Pintor J, Peral A, Hoyle $\mathrm{CH}$, et al. Effects of diadenosine polyphosphates on tear secretion in New Zealand white rabbits. J Pharmacol Exp Ther. 2002;300(1):291-297.

22. Pintor J, Bautista A, Carracedo G, Peral A. UTP and diadenosine tetraphosphate accelerate wound healing in the rabbit cornea. Ophthalmic Physiol Opt. 2004;24(3):186-193.

23. Mediero A, Peral A, Pintor J. Dual role of diadenosine polyphosphates on corneal epithelial cell migration. Invest Ophthalmol Vis Sci. 2006; $47(10): 4500-4506$.

24. Sharma GD, He J, Bazan HE. p38 and ERK1/2 coordinate cellular migration and proliferation in epithelial wound healing: evidence of cross-talk activation between MAP kinase cascades.J Biol Chem. 2003;278(24):21989-21997.

25. Saika S, Okada Y, Miyamoto T, et al. Role of p38 MAP kinase in regulation of cell migration and proliferation in healing corneal epithelium. Invest Ophthalmol Vis Sci. 2004;45(1):100-109.

26. Deng M, Chen WL, Takatori A, et al. A role for the mitogenactivated protein kinase kinase kinase 1 in epithelial wound healing. Mol Biol Cell. 2006;17(8):3446-3455.

27. Wilkinson MG, Millar JB. Control of the eukaryotic cell cycle by MAP kinase signaling pathways. FASEB J. 2000;14(14):2147-2157.

28. Hall A. Ras-related GTPases and the cytoskeleton. Mol Biol Cell. 1992;3(5):475- 479 .

29. Ridley AJ. Signal transduction through the GTP-binding proteins Rac and Rho. J Cell Sci Suppl. 1994;18:127-131.

30. Sander EE, Collard JG. Rho-like GTPases: their role in epithelial cell-cell adhesion and invasion. Eur J Cancer. 1999;35(14):19051911.

31. SundarRaj N, Kinchington PR, Wessel H, et al. A Rho-associated protein kinase: differentially distributed in limbal and corneal epithelia. Invest Ophthalmol Vis Sci. 1998;39(7):1266-1272.

32. Klepeis VE, Weinger I, Kaczmarek E, Trinkaus-Randall V. P2Y receptors play a critical role in epithelial cell communication and migration. J Cell Biochem. 2004;93:1115-1133.

33. Yang L, Crason D, Trinkaus-Randall V. Cellular injury induces activation of MAPK via P2Y receptors. J Cell Biochem. 2004;91: 938-950.

34. Weinger I, Klepeis VE, Trinkaus-Randall V. Tri-nucleotide receptors play a critical role in epithelial cell wound repair. Purinergic Signal. 2005;1:281-292.

35. Sauzeau V, Le Jeune H, Cario-Toumaniantz C, et al. P2Y(1), P2Y(2), $\mathrm{P} 2 \mathrm{Y}(4)$, and $\mathrm{P} 2 \mathrm{Y}(6)$ receptors are coupled to Rho and Rho kinase activation in vascular myocytes. Am J Physiol Heart Circ Physiol. 2000;278(6):H1751-H1761.

36. Crosson CE, Klyce SD, Beuerman RW. Epithelial wound closure in the rabbit cornea: a biphasic process. Invest Ophthalmol Vis Sci. 1986;27(4):464- 473 . 
37. Valster A, Tran NL, Nakada M, Berens ME, Chan AY, Symons M Cell migration and invasion assays. Methods. 2005;37:208-215.

38. Ashley N, Harris D, Poulton J. Detection of mitochondrial DNA depletion in living human cells using PicoGreen staining. Exp Cell Res. 2005;303(2):432-446.

39. Desai LP, Aryal AM, Ceacareanu B, Hassid A, Waters CM. RhoA and Rac1 are both required for efficient wound closure of airway epithelial cells. Am J Pbysiol Lung Cell Mol Pbysiol. 2005;287: L1134-L1144.

40. Lee JG, Kay EP. FGF-2-induced wound healing in corneal endothelial cells requires $\mathrm{Cdc} 42$ activation and rho inactivation through the phosphatidylinositol 3-kinase pathway. Invest Ophthalmol Vis Sci. 2006; 47(4):1376-1386.

41. Brunet A, Roux D, Lenormand P, Dowd S, Keyse S, Pouysségur J. Nuclear translocation of p42/p44 mitogen-activated protein kinase is required for growth factor-induced gene expression and cell cycle entry. EMBO J. 1999;18(3):664-674.

42. Guzman-Aranguez A, Crooke A, Peral A, Hoyle CHV, Pintor J. Dinucleoside polyphosphates in the eye: from physiology to therapeutics. Prog Retin Eye Res. 2007;26(6):674-687.

43. Ahmad S, Ahmad A, Ghosh M, Leslie CC, White CW. Extracellular ATP-mediated signaling for survival in hyperoxia-induced oxidative stress. J Biol Chem. 2004;279:16317-16325.

44. Delicado EG, Jimenez AI, Carrasquero LMG, Castro E, Miras-Portugal MT. Cross-talk among epidermal growth factor, $\operatorname{Ap}(5) \mathrm{A}$, and nucleotide receptors causing enhanced ATP $\mathrm{Ca}(2+)$ signaling in- volves extracellular kinase activation in cerebellar astrocytes. J Neurosci Res. 2005;81:789-796.

45. Douillet CD, Robinson WP 3rd, Milano PM, Boucher RC, Rich PB. Nucleotides induce IL-6 release from human airway epithelia via P2Y2 and p38 MAPK-dependent pathways. Am J Pbysiol Lung Cell Mol Pbysiol. 2006;291:L734-L746.

46. Bessard A, Coutant A, Rescan C, et al. An MLCK-dependent window in late G1 controls $S$ phase entry of proliferating rodent hepatocytes via ERK-p70S6K pathway. Hepatology. 2006;44(1): 152-163.

47. Pawlak G, Helfman DM. MEK mediates v-Src-induced disruption of the actin cytoskeleton via inactivation of the Rho-ROCK-LIM kinase pathway. J Biol Chem. 2002;277(30):26927-26933.

48. Roovers K, Assoian RK. Effects of rho kinase and actin stress fibers on sustained extracellular signal-regulated kinase activity and activation of G(1) phase cyclin-dependent kinases. Mol Cell Biol. 2003;23(12):4283-4294.

49. Suzuki K, Saito J, Yanai R, et al. Cell-matrix and cell-cell interactions during corneal epithelial wound healing. Prog Retin Eye Res. 2003;22(2):113-133.

50. Willard FS, Crouch MF. MEK, ERK, and p90RSK are present on mitotic tubulin in Swiss 3T3 cells: a role for the MAP kinase pathway in regulating mitotic exit. Cell Signal. 2001;13(9):653664 .

51. Wang R, He G, Nelman-Gonzalez M, Ashorn CL, et al. Regulation of Cdc25C by ERK-MAP kinases during the $G_{2} / M$ transition. Cell. 2007; 128:1119-1132. 